\title{
Patos Lagoon Estuary and Adjacent Marine Coastal Biodiversity Long-term data
}

Valéria M. Lemos ${ }^{1}$, Marianna Lanari ${ }^{1}$, Margareth Copertino $^{1}$, Eduardo R. Secchi ${ }^{1}$, 5 Paulo Cesar O. V. de Abreu ${ }^{1}$, José H. Muelbert ${ }^{1}$, Alexandre M. Garcia ${ }^{1}$, Felipe C. Dumont $^{1}$, Erik Muxagata ${ }^{1}$, João P. Vieira ${ }^{1}$, André Colling ${ }^{1}$ and Clarisse Odebrecht ${ }^{1}$

${ }^{1}$ Universidade Federal do Rio Grande (FURG), Instituto de Oceanografia, Rio Grande, C.P. 474, CEP 96203-900, BRAZIL

10 Correspondence to: Valéria Marques Lemos (vavadeleom@yahoo.com.br)

\begin{abstract}
Estuaries are among the most productive aquatic ecosystems and provide important ecological and economic services in coastal areas. However, estuarine systems have been threatened worldwide by natural and anthropogenic impacts acting on local, regional and global scales. Long-term ecological studies contribute to the understanding and management of estuarine functioning, and provide the baseline information for detection changes and modeling of predictive scenarios. Here, we describe long-term data on the biodiversity and physico-chemical parameters obtained from 1993 to 2016 for the Patos Lagoon estuary and adjacent marine coast, in southern Brazil. We report eight datasets containing 6,972 sampling events with the occurrence and abundance records of 275 species (Kingdoms: Bacteria, Protozoa, Chromista, Plantae and Animalia) of functional groups plankton, benthos and nekton. Datasets also include 22,190 abiotic records. Database is published in the Global Biodiversity Information Facility (GBIF) repository (see Data availability in Sect 3). The present compendium represents one of the most comprehensive and longest datasets from primary producers to top predators in an estuarine-coastal system in South America and their availability will be an important contribution to the understanding and predictability of estuarine dynamics around the world.
\end{abstract}

\section{Introduction}

30 Coastal and marine biodiversity are facing an unprecedented worldwide threat from climate change, pollution, overfishing, habitat destruction, and invasive species (Lotze et al., 2006; Christian and Mazzilli, 2007; Halpern et al., 2008; Kennish and Paerl, 2010; Doney and Schimel, 2015) impairing the ecosystem functions and the delivery of goods and services to society. The comprehension of most of those threats requires knowledge of the long-term variability of both biological and environmental variables, which are the baseline for ecological studies and for the detection of early warning signals of natural and anthropogenic impacts and the modeling of predictive scenarios (Vihervaara et at., 2013; Muelbert et al., 2019). The establishment and maintenance of ecological observations of coastal ecosystems are crucial to support scientists and stakeholders with the necessary information to quantify environmental changes and their impact on the biodiversity and the sustainable use of the seas and coasts (Muelbert et al., 2019). That information is crucial to implement conservation and sustainable development targets (e.g. evaluating progress toward Aichi Targets of the Convention on Biological Diversity (CBD) (Dreujou et al., 2020) and several of the U.N. Sustainable Development Goals), and to 
enable global assessments such as those by the Intergovernmental Platform on Biodiversity and Ecosystem Services (IPBES) and the UN World Ocean Assessment (Duffy et al., 2013).

Our current understanding of marine ecosystem responses to human activities is limited by the availability of data, particularly long-term series of physical, chemical, and biological conditions (Carstensen, 2014). Despite the important global initiatives (e.g. International Long-Term Ecological Research) long-term, integrated, ecosystem-level monitoring efforts are still scarce for most coastal and marine ecosystems (Kennish and Paerl, 2010; Duffy et al., 2013; Vihervaara et at., 2013; Muelbert et al., 2019), particularly in Southern Hemisphere (Odebrecht et al., 2017). The scarcity of temporal data series from coastal ecosystems hampers the assessment of the impacts and undermines our ability to respond effectively to these threats (Turra and Denadai, 2016).

Estuaries and nearshore coastal regions are some of the most productive ecosystems on earth (McLusky and Elliott, 2004), yet among the most affected by human activities and climate changes (Ruiz et al., 2000). In southern Brazil, the Patos Lagoon Estuary and adjacent marine coast (PLEA) have been long recognized (Von Ihering, 1885) by their high biological productivity, together with human interference (Odebrecht et al., 2017). Considered the largest choked lagoon in the world (Kjerfve, 1986), the Patos Lagoon connects the continental waters to the western South Atlantic Ocean and performs a critical role on the regional economy (Seeliger, 2001). The favorable natural conditions and strategic position led to

60 the development of local and regional economic activities associated with artisanal and industrial fisheries (Kalikoski and Vasconcellos, 2012; Haimovici et al., 2014; Haimovici and Cardoso, 2017), port activities, industry and tourism (Newton et al., 2018).

The PLEA has been a Site of the Brazilian Long-Term Ecological Research Program (LTER) since 1998, although oceanographic and ecological studies started in the 1970s (Odebrecht et al., 2017). The

LTER-PLEA (PELD-ELPA, in Portuguese) is a well-established and consolidated monitoring program, producing amongst the longest datasets on estuarine/marine biota and abiotic parameters in South Hemisphere (Odebrecht et al., 2010; 2017). Together with other ILTER coastal and marine sites (about 120 around the globe) (Muelbert et al., 2019), LTER-PLEA has a great potential to contribute to global coastal and ocean observation.

70 The LTER-PLEA contributes with information about the biota composition, distribution, and abundance at seasonal, interannual and decadal time scales, providing the basis to understand the estuarine ecological processes and their driving forces. Many studies have demonstrated how the variability in climate and hydrology influences the ecology of estuarine and marine biodiversity and production (Seeliger and Odebrecht, 2010; Odebrecht et al., 2010; 2017). PLEA is affected by largescale and remote phenomena, the most important being the El Niño Southern Oscillation (ENSO), which strongly influences southern South America precipitation and fluvial discharge discharge (Robertson and Mechoso, 1997; Grimm et al., 1998). The interactions among climate and hydrology directly affect the dynamics of plankton (Muxagata et al., 2012; Haraguchi et al., 2015; Odebrecht et al., 2015; Abreu et al., 2016; Teixeira-Amaral et al., 2017; Salvador and Muelbert, 2019), macroalgae, seagrasses, benthic invertebrates (Colling et al., 2010; Lanari and Copertino, 2017; Lanari et al., 2018) and fish (Garcia et al., 2001; 2003; Vieira et al., 2010; Moraes et al., 2012; Garcia et al., 2017), with implications for species conservation (Costa et al., 2016), including fishing resources (Castello and Möller, 1978; Odebrech and Castello, 2001; Vieira et al., 2008). Impacts of human activities such as 
overfishing and dredging, combined with the ENSO, have the potential to result in changes in biodiversity and ecological functions. Therefore, the PLEA is an ideal environment to test hypotheses about changes in biodiversity and their functioning at several temporal scales.

Here, we describe a database comprising biological parameters within plankton, benthos, and nekton communities, from primary producers to top predators, and associated water physical-chemical parameters. The compendium represents one of the most robust and longest databases of biological

90 diversity in an estuarine-coastal system of South America. The dataset is the framework for understanding the structure and functioning of PLEA and can be an important tool for environmental management and decision-making. Furthermore, the data provide information for the modeling of predictive scenarios of climate changes impacts, which are fundamental for local adaptation and mitigation strategies, but also to a better understanding of coastal environments dynamics and functioning.

\section{Data and methodology}

\subsection{Geographical coverage}

100 The Patos Lagoon Estuary is part of the Patos-Mirim Lagoon system located in the subtropical coastal plain of southern Brazil (Fig. 1). The geographical coverage of the dataset ranges from $32^{\circ} 10^{\prime} 12^{\prime \prime} \mathrm{S}$ to $31^{\circ} 57^{\prime} 36^{\prime \prime} \mathrm{S}$ Latitude and from $52^{\circ} 15^{\prime} 36^{\prime \prime} \mathrm{W}$ to $52^{\circ} 0{ }^{\prime} 36^{\prime \prime} \mathrm{W}$ Longitude. The estuarine region $(\sim 10,360$ $\mathrm{km}^{2}$ ) consists mainly of shallow areas (i.e., $75 \%$ of the total area is $<2 \mathrm{~m}$ ), except for natural channels (3-5 $\mathrm{m}$ deep) and the main navigation channel ( $14 \mathrm{~m}$ deep). The estuary receives freshwater from a $200,000 \mathrm{~km}^{2}$ drainage basin and is under the influence of a microtidal regime $(\sim 0.47 \mathrm{~m})$ strongly attenuated by the single and narrow entrance channel ( 0.5 to $3 \mathrm{~km}$ wide). Hydrology is driven mainly by fluvial discharge and wind patterns and on an annual basis, the estuary can be river dominated, display a salt wedge, become partially mixed or even a well mixed system (Möller et al., 2001). Marine and euhaline conditions occur in summer/autumn whereas oligohaline conditions in general prevail in winter/spring (Möller et al., 2001). 

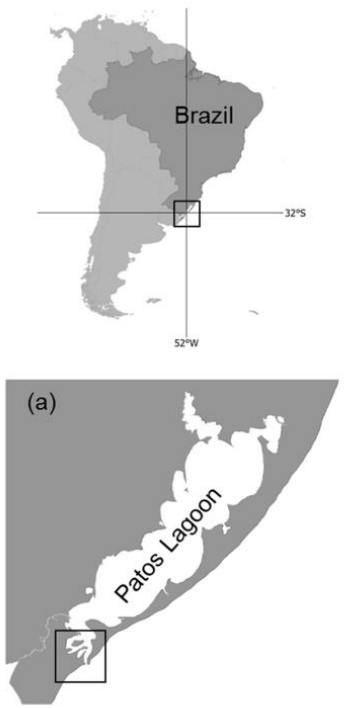

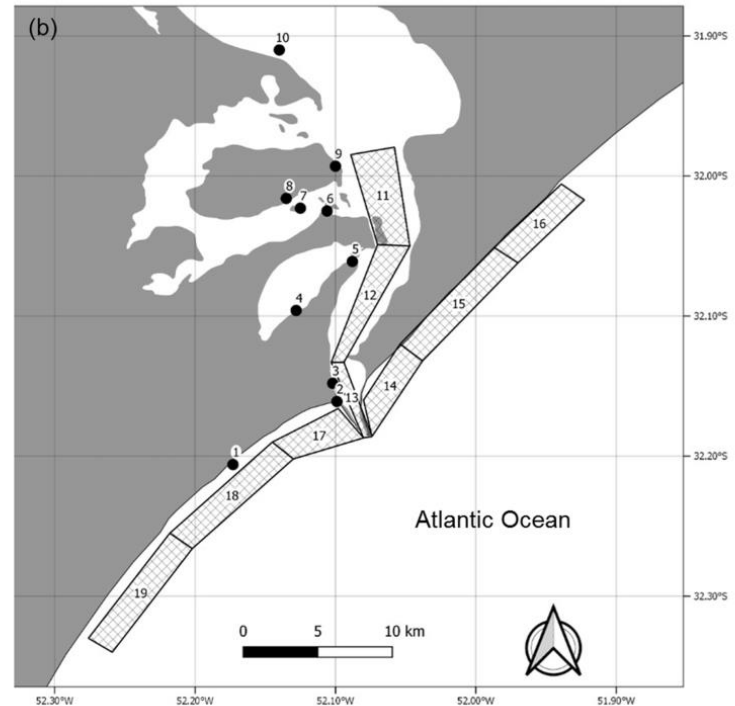

Figure 1: Study area. (a) Patos Lagoon, South of Brazil. (b) Map of the sampling points in the Patos Lagoon estuary and adjacent marine coast for the LTER-PLEA's datasets samplings. The sampling points are described in Table 1.

Interannual variability in hydrological patterns is largely associated with ENSO remote effects on regional precipitation, with anomalous high/low freshwater run-off occurring during El Niño/La Niña years, respectively (Odebrecht et al., 2010). Overall, high levels of nutrients in the water column (up to $40 \mu \mathrm{M}$ NO2-+NO3-, $40 \mu \mathrm{M}$ NH4+ and $8.7 \mu \mathrm{M}$ PO43-) and sediment (up to $710.7 \mu \mathrm{M}$ NH4+ and 14.6 $\mu \mathrm{M}$ PO43-) are maintained through inputs from the watershed, macrophytes and anthropogenic sources (Baumgarten and Niencheski, 2010; Odebrecht et al., 2010).

\subsection{Data description}

125 The data described is a product of the Brazilian Long-Term Ecological Research Program in the Patos Lagoon estuary and adjacent marine coast - LTER-PLEA established in 1998. The program aims to investigate the main natural and anthropic impacts on biotic and abiotic components of this ecosystem. Distinct areas of the PLEA have been monitored generating a core set of measurements repeated over time across spatial gradients (Fig. 1, Table 1). Eight datasets, covering the biota (phyto-, zoo-, and ichthyoplankton, benthic macrofauna, seagrasses, macroalgae, pink shrimp, fishes and marine mammals - dolphins) and associated physical and chemical water parameters (salinity, temperature, transparency, chlorophyll $a$, inorganic dissolved nutrients, and seston) was obtained by several research groups and laboratories that systematically and almost simultaneously monitor the estuary (Fig. 2a) at different temporal scales (daily, monthly, and seasonal) (Table 2). Some datasets include sampling 


\begin{tabular}{|c|c|c|c|c|}
\hline $\begin{array}{l}\text { Station } \\
\text { number }\end{array}$ & Location & Latitude & Longitude & Dataset \\
\hline 1 & $\begin{array}{l}\text { Beach station / Cassino } \\
\text { beach / EMA }\end{array}$ & -32.206 & -52.173 & I, II, III,VI and VII \\
\hline 2 & Molhes & -32.161 & -52.099 & III,VI and VII \\
\hline 3 & $\begin{array}{l}\text { Bar station / Channel / } \\
\text { Prainha }\end{array}$ & -32.148 & -52.102 & I, II, III, VI and VII \\
\hline 4 & Mangueira & -32.096 & -52.128 & III,VI and VII \\
\hline 5 & Franceses & -32.061 & -52.088 & III, VI and VII \\
\hline 6 & $\begin{array}{l}\text { Museum station / Inner } \\
\text { estuary }\end{array}$ & -32.025 & -52.106 & I and II \\
\hline 7 & Pombas / Ponto 1 & -32.023 & -52.125 & IV and $\mathrm{V}$ \\
\hline 8 & Porto Rei & -32.016 & -52.135 & III, VI and VII \\
\hline 9 & Marambaia & -31.993 & -52.100 & III, VI and VII \\
\hline 10 & Torotama & -31.91 & -52.14 & VI and VII \\
\hline 11 & E3. Inner estuary & 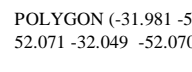 & $2.054-32.049-52.070,-31.981-$ & VIII \\
\hline 12 & E2. Medium estuary & $\begin{array}{l}\text { POLYGON }(-32.049-5 \\
52.070-32.133-52.103\end{array}$ & $2.047-32.133-52.103,-32.049-$ & VIII \\
\hline 13 & E1. Mouth of estuary & $\begin{array}{l}\text { POLYGON }(-32.133-5 \\
52.103-32.187-52.080\end{array}$ & $52.094-32.187-52.080,-32.133-$ & VIII \\
\hline 14 & N1. Adjacency north & $\begin{array}{l}\text { POLYGON (-32.160 -5 } \\
52.080-32.12-52.054,\end{array}$ & $2.074-32.12-52.054,-32.160$ - & VIII \\
\hline 15 & N2. Medium north & $\begin{array}{l}\text { POLYGON (-32.12 -52 } \\
52.054-32.051-51.987\end{array}$ & 2.038 - $32.051-51.987,-32.12$ - & VIII \\
\hline 16 & N3. Further north & $\begin{array}{l}\text { POLYGON (-32.051 -5 } \\
51.987-31.983-51.915\end{array}$ & $1.970-31.983-51.915,-32.051-$ & VIII \\
\hline 17 & S1. Adjacency south & $\begin{array}{l}\text { POLYGON }(-32.166-5 \\
52.098-32.19-52.145 \text {, }\end{array}$ & $52.080-32.19-52.145,-32.166-$ & VIII \\
\hline 18 & S2. Medium south & $\begin{array}{l}\text { POLYGON (-32.19-52 } \\
52.145-32.255-52.218\end{array}$ & 2.130 - $-32.255-52.218,-32.19-$ & VIII \\
\hline 19 & S3. Further south & $\begin{array}{l}\text { POLYGON }(-32.255-5 \\
52.218-32.330-52.276\end{array}$ & $2.202-32.330-52.276,-32.255-$ & VIII \\
\hline
\end{tabular}




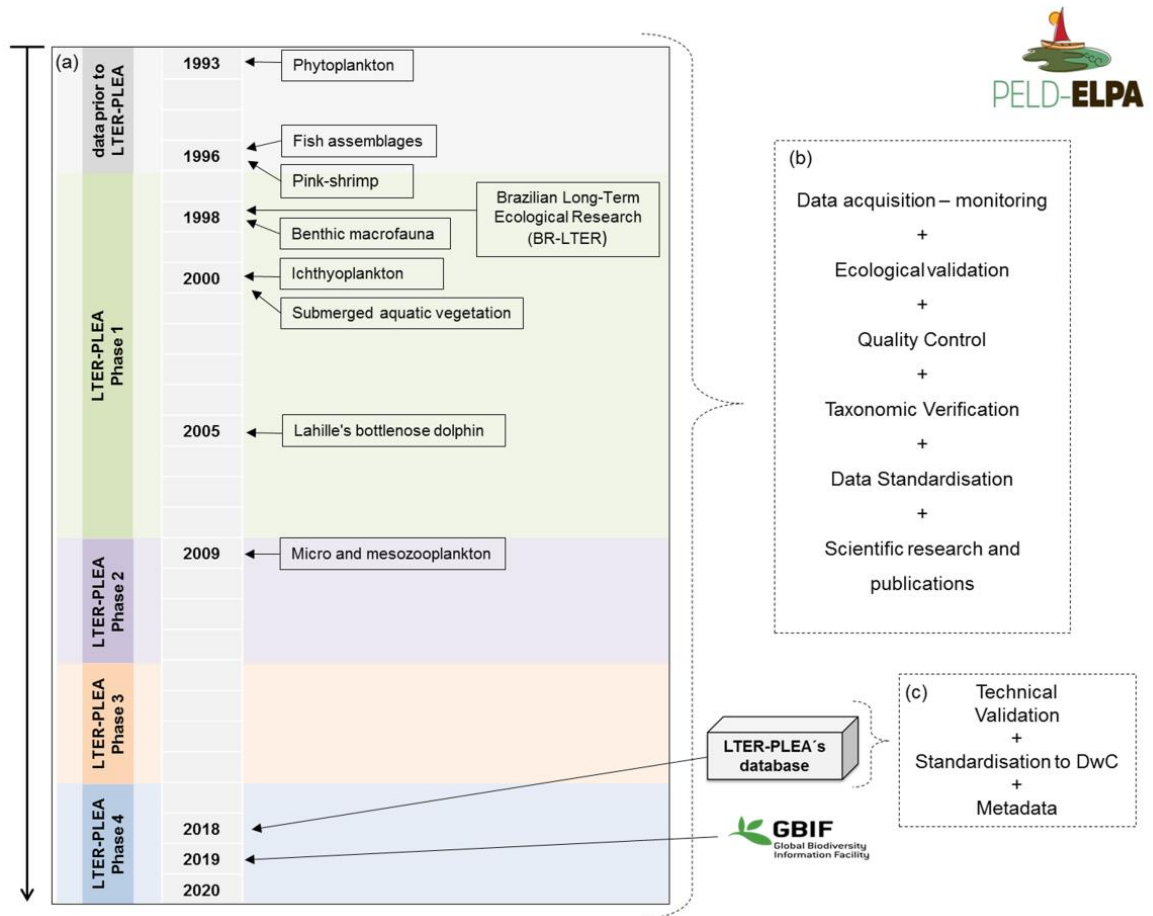

140 Figure 2: Stages of the LTER-PLEA's database life cycle: from data collection to integration in GBIF. (a) LTER-PLEA timeline, (b) Quality Assurance and Control process, (c) Technical validation process, formatting and registration of the LTER-PLEA's database in Global Biodiversity Information Facility (GBIF). 
Table 2. Temporal coverage of the LTER-PLEA's datasets.

\begin{tabular}{cllc}
\hline DataSet & \multicolumn{1}{c}{ Biotic components } & \multicolumn{1}{c}{ Temporal Coverage } & Sampling frequency \\
\hline I & Phytoplankton & January, 1993 to December, 2016 & Monthly \\
II & Micro and mesozooplankton & April, 2009 to December, 2016 & Monthly \\
III & Ichthyoplankton & October, 2000 to December, 2016 & Monthly \\
IV & Submerged Aquatic Vegetation & January, 2000 to May, 2016 & Monthly \\
V & Benthic macrofauna & March, 1998 to August, 2016 & Semiannually \\
VI & Pink-shrimp Penaeus paulensis & October, 1996 to December, 2016 & Monthly \\
VII & Fish & August, 1996 to December, 2016 & Monthly \\
VIII & Lahille's bottlenose dolphin Tursiops & August, 2005 to December, 2016 & Weekly \\
\hline
\end{tabular}

Datasets: I. Phytoplankton and water quality parameters in the Patos Lagoon estuary and adjacent marine coast; II. Continuous monitoring of the micro and mesozooplankton of the Patos Lagoon estuary and adjacent coastal area; III. Interannual variability of ichthyoplankton diversity in the Patos Lagoon estuary Southern Brazil; IV. Dynamics of submerged aquatic vegetation in the Patos Lagoon estuary; V. Temporal data series of Benthic macrofauna abundance and composition from the Patos Lagoon estuary; VI. Ecology of the pink-shrimp Penaeus paulensis in Patos Lagoon estuary; VII. Species composition and abundance patterns of fish assemblages at shallow waters of Patos Lagoon estuary; VII. Ecology of Lahille's bottlenose dolphin Tursiops truncatus gephyreus in the Patos Lagoon estuary and adjacent marine coast.

\subsection{Data sources and sampling protocol}

The eight datasets was based on the use of distinct sampling strategies and methods, according to the

150 goals and specific characteristics of the biotic and abiotic components investigated. Consistency in data collection was continually emphasized, and was assisted by continued participation of the same researchers over the time period.

\subsubsection{Phytoplankton (Dataset - I)}

155 Sampling description: Phytoplankton was sampled monthly at two stations located in the estuary of the Patos Lagoon and one at Cassino Beach (Fig. 1, Table 1). Phytoplankton for qualitative analysis was sampled by horizontal tows using a $20 \mu \mathrm{m}$-mesh size plankton net and stored in glass bottles fixed with fomaldehyde $(4 \%)$ neutralized with hexamethylentetramine. For phytoplankton quantitative (cells counting) analysis, surface water samples were stored in ambar glass bottles and fixed with lugol's solution (2\%). Phytoplankton composition and abundance were obtained using the classical Utermöhl sedimentation method and described elsewhere (Odebrecht et al., 2010; Haraguchi et al., 2015). Six persons (graduate students, technician, researcher) counted phytoplankton over the whole study period using the same procedure, i.e., screening of half (density of predominant species $>100$ units) or the entire sedimentation chamber for organisms larger than $50 \mu \mathrm{m}$ under low magnification $(100 \mathrm{x})$ using an optical microscope (Inverted microscope Zeiss). Smaller organisms were counted according to the cell density, under magnification of $200 \mathrm{x}$ and/or $400 \mathrm{x}$, in strips or at least 30 fields.

The routine identification of phytoplankton morpho-species was conducted under optical microscopy (inverted and transmitted light, Zeiss) and followed classical literature (Balech, 1988; Tomas, 1993; 1996; Hoppenrath et al., 2009) and specific taxonomic articles. Electron microscopy was used for the 

al., 2011). Thalassiosira, however, was identified and counted to genus level due to identification difficulties using the optical microscope (Garcia and Odebrecht, 2009). Other difficulties to identify species were grouped at higher taxonomic levels (i.e., centric and pennate diatoms, armored or unarmoured gymnodinioid dinoflagellates). Also, small flagellates $(<20 \mu \mathrm{m})$ and coccoid cells were grouped and counted in size classes. Molecular biology tools were applied to species of Asterionellopsis (Franco et al., 2016) and Pseudo-nitzschia (Hagström et al., 2011). Non-identifiable or damaged specimens were annotated as NA (not available). The autotrophic ciliate Mesodinium was included in the present dataset.

The physical water parameters were obtained in situ: temperature (mercury thermometer), salinity (optical refractometer or conductivity meter Yellow Spring, mod. 33 SCT) and water transparency (Secchi disk). Surface water samples were obtained using a bucket, stored in plastic bottles and maintained in dark, for the analysis of dissolved inorganic nutrients and chlorophyll $a$ (Abreu et al., 2010; 2016). In the laboratory, $50-100 \mathrm{~mL}$ water aliquots were filtered (Whatman GF/F glass fibre filters) and frozen $\left(-40^{\circ} \mathrm{C}\right)$ for the analysis of dissolved inorganic silicate, phosphate and nitrite + nitrate, while ammonium and chlorophyll $a$ (material retained on the filters) analysis were conducted right away. The concentration of the former nutrients was measured according to the methods described by Strickland and Parsons (Strickland and Parsons, 1972), and that of ammonium followed the method of UNESCO (1983). For the chlorophyll $a$ concentration analysis, pigments were extracted (acetone solution $90 \% \mathrm{v} / \mathrm{v}$ ) in the dark and cold for $24 \mathrm{~h}$, and measured using a calibrated Turner Design

190 fluorometer with correction for degradation products (Strickland and Parsons, 1972; Welschmeyer, 1994).

Quality Assurance and Control (QA/QC): Same researchers and methods were employed since the beginning of the study period. Thus, methodology influence is minimal. Technical assistance for sampling and nutrient analysis changed during the years, and of phytoplankton counting (six persons), but always under supervision of the same responsible researchers. However, every time a new methodology was applied, duplicated analyses were carried on with the old and new methods in order to determine the error levels of measurements. The species nomenclature was updated following the evolution of taxonomic and systematic new studies.

\subsubsection{Micro and mesozooplankton (Dataset - II)}

Sampling description: Zooplankton samples were collected monthly at three stations located in the estuary of the Patos Lagoon and Cassino Beach (Fig. 1, Table 1). Zooplankton samples at the estuary were collected from sub-superficial horizontal tows of $\sim 3$ min using mini bongo frames of $30 \mathrm{~cm}$ of diameter fitted with 200 and $90 \mu \mathrm{m}$-meshes with calibrated Hydro-Bios flowmeters attached to the mouth of each net. For Cassino Beach, were used a conventional $30 \mathrm{~cm}$ diameter frame fitted with a $200 \mu \mathrm{m}$-mesh and a calibrated TSK flowmeter. All samples were immediately preserved in a $4 \%$ borax buffered formaldehyde solution (Steedman, 1976) until processing.

All zooplankton organisms present on subsamples of 1.25 to $50 \%$ of the $200 \mu \mathrm{m}$-mesh samples, were counted on a stereoscopic microscope and identified to the lowest taxonomic level possible. All results 
210 are expressed in numbers of organisms. $\mathrm{m}^{-3}$. Copepod species were identified according to Rose (1933), Björnberg (1981) and Bradford-Grieve (1999), barnacle nauplii according to Lang (1979; 1980), and the remaining species and/or groups using specific references on Boltovskoy (1981; 1999). Nonidentifiable or damaged specimens were recorded as NA (not available).

On each station water samples of 20 to $100 \mathrm{~mL}$ were collected and filtered through $2.5 \mathrm{~cm}$ glass microfiber filters (Whatman GF/F) using a syringe with a filter holder attachment (Swinnex). Each filter paper was then folded in half, wrapped in foil and frozen until processing. Chlorophyll a was extracted with $90 \%$ acetone and readings were made on a calibrated Turner Designs Fluorometer (TD 700) according to Welschmeyer (1994). Temperature and salinity were also measured on each station using a thermosalinometer (Hanna HI 9828), refractometers and a mercury thermometer depending on availability.

Quality Assurance and Control (QA/QC): All samples were collected under the supervision of planktologists or graduate students of the zooplankton laboratory, and the taxonomic quality of the data was checked before uploading the database.

\section{$225 \quad$ 2.3.3 Ichthyoplankton (Dataset - III)}

Sampling description: Ichthyoplankton samples were collected monthly at seven stations located in the estuarine margins of the Patos Lagoon and adjacent marine coast of Cassino Beach (Fig. 1, Table 1). Sampling of fish eggs and larvae was made with a $50 \mathrm{~cm}$ diameter $300 \mu \mathrm{m}$-mesh conical net equipped with a flowmeter. The net was manually hauled on the beach area by two people during two minutes at the seven stations. In the laboratory, samples were concentrated in $300 \mathrm{ml}$ jars and all fish eggs and larvae were sorted from the remainder zooplankton. All the collected material was preserved in formaldehyde $4 \%$.

In the laboratory, the material was screened and identified. Fish eggs and larvae were identified to the lowest taxonomic level possible according to Weiss (1981), Fahay (1983), Moser (1996), Olivar et al. (1999) and Richards (2005). Non-identifiable or damaged specimens were recorded as NA (not available). Total abundance was recorded by taxa as an absolute number and standardized to a volume of $100 \mathrm{~m}^{3}$.

Temperature and salinity were registered with a YSI Thermosalinometer with precision of $0.01^{\circ} \mathrm{C}$ and of 0.01 salinity units.

240 Quality Assurance and Control (QA/QC): Sampling and laboratory procedure was conducted under the same supervision and with the same standardized technique during this period. Taxonomic determination was done by the same qualified technical expert for the entire period so far. Data was double checked for typing errors and inadequate values.

\subsubsection{Submerged aquatic vegetation (Dataset - IV)}

Sampling description: The submerged aquatic vegetation (SAV) was monthly monitored in a shallow area historically occupied by Ruppia maritima meadows and drift green macroalgae, at an inner and protected shoal within the mesomixohaline region of Patos Lagoon Estuary (Fig. 1, Table 1). The sampling design aimed to cover the center of the meadow and their ending limits, covering 

and distant $500 \mathrm{~m}$ of Pombas Island. The permanent transect was marked by six fixed wooden, buried two-three meters into the sediment. Surrounding each fixed post, the percentage cover of rooted plants and macroalgae were quantified within randomized $25 \times 25 \mathrm{~cm}$ quadrats $(\mathrm{N}=3)$. Within each quadrat, the plant biomass was sampled by using cylindrical cores, buried into the sediment $(\varnothing 10 \mathrm{~cm}, 15 \mathrm{~cm}$ depth) ( $\mathrm{N}=3$ per plot; total $\mathrm{N}=18)$. The samples previously washed in the field with the help of sieves, were packed and transported to the laboratory with ice.

In the laboratory, the biomass samples were washed and cleaned from sediments, debris, and associated fauna. The plant biomass was split into functional groups: rooted plants, macroalgae and epiphyte algae. The rooted plants were divided into belowground and aboveground fractions. Plant development and phenology was recorded. Epiphyte algae were removed, by scraping the leaves with a surgical blade. Demographic parameters were obtained for the rooted plants such as: hast length, leaf length, number of shoots, total rhizome length, number of nodes along the rhizome. The dry weight $(48 \mathrm{~h}$ at $60^{\circ} \mathrm{C}$ ) was obtained for each functional group and rooted plant compartments (belowground and aboveground).

Quality Assurance and Control (QA/QC): Samples were always collected by researchers or trained students. Soon after sample trial and parameters measures, data was compiled and basic statistics (average, standard deviations) were applied. Data were visualized and analyzed by graphical exploration approaches for detecting anomalies and errors. In addition, new data were always checked against historical data for comparison and identification of patterns.

270 Technical information: With the drastic reduction in seagrasses abundance, detected in Patos Lagoon and across the Brazilian coast (Copertino et al., 2016), the methodology was revaluated to integrate a national network approach. Therefore, this particular SAV data set was discontinued in 2016 and a new field protocol was initiated according to the Benthic Monitoring Network (known as ReBentos protocol in Brazil) (Copertino et al., 2015). The ReBentos protocol includes surveys and observations in three sites within Patos Lagoon estuary, exposed to different environmental conditions (salinity, transparency, nutrient input, anthropogenic impacts). In addition to percentage cover, biomass and demographic parameters recorded across three transects (in each site), the ReBentos protocol includes information about sediment and water parameters, and seagrass meadow area.

\subsubsection{Benthic macrofauna (Dataset - V)}

Sampling description: The Benthic macrofauna samples were collected at four stations located in the estuary of the Patos Lagoon (Fig. 1, Table 1). Data have been acquired twice a year, comprising winter (August) and summer (March) samplings. The samples were taken with a $10 \mathrm{~cm}$ diameter PVC corer $\left(0.0078 \mathrm{~m}^{2}\right)$ buried $20 \mathrm{~cm}$ into the substrate and sieved through a $300 \mu \mathrm{m}$-mesh (Gray and Elliott, 2009). All collected material was fixed in formaldehyde $4 \%$ and preserved in ethanol (70\%).

The macrofauna specimens were identified to the lowest taxonomic level (Amaral and Nonato, 1996; Buckup and Bond-Buckup, 1999; Rios, 2009) and quantified with the aid of stereomicroscopes (40 x) in the Laboratory. The abundance data for each point represent the number of organisms for each species collected by the PVC corer. 
290 Quality Assurance and Control (QA/QC): Sampling was done by qualified technical experts continuously trained to use the same techniques and methods. The quality of data was checked monthly before the uploading in the data bank. Data is checked for typing errors under supervision of experienced researchers.

\subsubsection{Pink-shrimp Penaeus paulensis (Dataset - VI)}

Sampling description: The pink-shrimp samples were collected monthly at eight stations (Fig. 1, Table 1) located in the estuary of the Patos Lagoon and Cassino Beach with five replicates each. The gear used to obtain biological samples was a beach seine ( $9 \mathrm{~m}$ in length, $13 \mathrm{~mm}$ (adjacent knots) and $5 \mathrm{~mm}$ in the center), an active net designed to operate in shallow regions (average depth lower than $1.5 \mathrm{~m}$ ). The pink-shrimp samples were preserved in $10 \%$ formalin and later identified in the laboratory according to Buckup and Bond-Buckup (1999).

The water temperature (mercury thermometer), salinity (refractometer) and transparency (Secchi disk) data were collected at each sampling station.

Quality Assurance and Control (QA/QC): Researchers and the classical methods were the same employed since the beginning of the time series. Thus, methodology influence is minimal. Sampling was always performed under supervision of experienced researchers.

\subsubsection{Fish assemblages (Dataset - VII)}

Sampling description: The ichthyofauna samples were collected monthly at eight stations located in the estuary of the Patos Lagoon and the adjacent marine coast (Cassino Beach) (Fig. 1, Table 1). Fishes were sampled using a $9 \mathrm{~m}$ beach seine $(13 \mathrm{~mm}$ bar mesh in the wings and $0.5 \mathrm{~mm}$ mesh adjacent knots in the $3 \mathrm{~m}$ center section) that was pulled to cover an area of about $60 \mathrm{~m}^{2}$ during each haul. Five hauls were made monthly (usually in the first week of each month) at each sampling station. After sampling, fishes were euthanized using Eugenol (CONCEA, 2013) and stored in plastic bags with $10 \%$ formalin. In the laboratory, fishes were transferred to $70 \%$ alcohol. Fishes were then identified to the lowest taxonomic level possible according to specialized literature, such as Figueiredo (1977), Menezes and Figueiredo (1980; 1985), Figueiredo and Menezes (1978; 1980; 2000), Fischer et al. (2004), and Fishbase (Froese and Pauly, 2019).

Concomitant with fish sampling, the water temperature (mercury thermometer), salinity (refractometer) and transparency (Secchi disk) data were collected at each station.

Quality Assurance and Control (QA/QC): Principal investigators and fishing gears were the same since the beginning of the time series. Fish sampling in one of the sampling stations (Marambaia) had to be discontinued in 2013 due to physical changes in the site that prevented beach seining. Sampling and species identification methods were consistent across the years of the study and occurred under the supervision of the same principal investigators.

2.3.8 Lahille's bottlenose dolphin Tursiops truncatus gephyreus (Dataset - VIII) 
Sampling description: The area sampled is $140 \mathrm{~km}^{2}$ and encompasses the lower portion of the Patos Lagoon estuary $\left(40 \mathrm{~km}^{2}\right)$ and adjacent marine coast $\left(50 \mathrm{~km}^{2}\right.$ south and $50 \mathrm{~km}^{2}$ north of Patos Lagoon estuary in the coastal zone) (Fig. 1, Table 1).

Distribution patterns and habitat use: All field work was carried out onboard a $5.6 \mathrm{~m}$-long inflatable boat equipped with a $90 \mathrm{hp}$ outboard engine, VHF radio, echo sounder and GPS. Boat-based surveys were conducted year-round on the core area of Patos Lagoon estuary dolphin community. Surveys in estuarine waters were conducted following predefined zigzag transects whereas in the adjacent marine coast either zigzag or parallel-to-shore transects up to $20 \mathrm{~km}$ north and south of the estuary mouth were run, depending on the sea conditions and objective of the sampling occasion. This variation, however, does not interfere in the nature and quality of data inserted in the database. Surveys were halted when the sea state (Beaufort scale) were $>3$. Transects were run at speeds between 18 and $22 \mathrm{~km} / \mathrm{h}$. Two observers positioned in the bow searched for dolphins visually. Whenever a dolphin group was sighted, the survey route was abandoned to approach the animals for photo-identification, for skin/blubber biopsy sampling and to obtain data of group size and composition, sighting depth and geographical position. After a sufficient number of good-quality digital photographs of the dorsal fins of presumably all animals were taken, the survey was resumed.

Quality Assurance and Control (QA/QC): Principal investigators and major sampling protocols remained the same since the beginning of the study. Adaptations to sampling procedures were eventually made for specific research questions but do not interfere in the content and quality of the dataset presented in this compendium.

\subsection{Data management and standardization}

350 LTER-PLEA's database sharing was performed based on the FAIR principles, which ensures that all data are easily findable, accessible, interoperable and reusable (Wilkinson et al., 2016; Tanhua et al., 2019). Thus, the potential of these data is summarized in: Findable, by the integration and dissemination of data and metadata through Global Biodiversity Information Facility (GBIF; www.gbif.org) with unique and persistent identifiers assigned (Table 3); Accessible, by open and free access to the data and metadata through friendly tools; Interoperable, by standardizing data in an internationally, widely accepted controlled vocabulary and spreadsheets structure; and Reusable: by providing a complete description of the dataset in GBIF metadata sections and in the presented data descriptor. Data management followed the steps below (Fig. $2 \mathrm{~b}$ and $2 \mathrm{c}$ ):

1. Data holders supplied their datasets to database manager in digital format (e.g., spreadsheets, csv files);

2. Data were checked by the researchers responsible for data and by the data manager for automatic and manual corrections (see Quality Assurance and Control in Sect 2.3) section for more details);

3. Datasets were formatted according to the Darwin Core (DwC) standard (TDWG, 2015) and the OBIS-ENV-DATA format (De Pooter et al., 2017);

4. Technical validation process (Taxonomic and Structural validation);

5. The metadata were described and verified by the responsible researchers; 
6. The resulting database was published in the GBIF platform through the Integrated Publishing Toolkit (IPT) provided by the Information System on Brazilian Biodiversity (SIBBr;

\begin{tabular}{|c|c|c|}
\hline Dataset & Dataset Name & Description \\
\hline I & $\begin{array}{l}\text { Phytoplankton and water quality parameters in the Patos Lagoon estuary } \\
\text { and adjacent marine coast (https://doi.org/10.15468/xmlvxm) (Odebrecht } \\
\text { and Abreu. 2020) }\end{array}$ & $\begin{array}{l}\text { The long-term information enabled the evaluation of environmental } \\
\text { and phytoplankton variability in the study region. }\end{array}$ \\
\hline II & $\begin{array}{l}\text { Continuous monitoring of the micro and mesozooplankton of the Patos } \\
\text { Lagoon estuary and adjacent coastal area } \\
\text { (https://doi.org/10.15468/1 xkowr) (Muxagata and Teixeira-Amaral, } \\
\text { 2020) }\end{array}$ & $\begin{array}{l}\text { The long-term information enabled the monitor seasonal and inter- } \\
\text { annual changes in the composition, distribution, abundance and } \\
\text { production of zooplanktonic species related to climatic events and } \\
\text { antropogenic causes. }\end{array}$ \\
\hline III & $\begin{array}{l}\text { Interannual variability of ichthyoplankton diversity in the Patos Lagoon } \\
\text { estuary Southern Brazil (https://doi.org/10.15468/noeqwa) (Muelbert, } \\
\text { 2020) }\end{array}$ & $\begin{array}{l}\text { Fish eggs and larvae were sampled to study temporal variability of the } \\
\text { dynamics of recruitment and diversity of ichthyoplankton in the } \\
\text { estuary of the Patos Lagoon end marine adjacent coast. }\end{array}$ \\
\hline IV & $\begin{array}{l}\text { Dynamics of Submerged Aquatic Vegetation in the Patos Lagoon estuary } \\
\text { (https://doi.org/10.15468/bjzlnb) (Copertino, 2020) }\end{array}$ & $\begin{array}{l}\text { The annual and interannual variability of the biomass, demographic } \\
\text { parameters and composition of submerged aquatic vegetation was } \\
\text { analyzed in relation to the regional climate, hydrology and physical } \\
\text { chemical parameters obtained by LTER - PLEA. }\end{array}$ \\
\hline $\mathrm{v}$ & $\begin{array}{l}\text { Temporal data series of Benthic macrofauna abundance and composition } \\
\text { from the Patos Lagoon estuary (https://doi.org/10.15468/lsoc2v) } \\
\text { (Colling and Cavalca Bom, 2020) }\end{array}$ & $\begin{array}{l}\text { Species composition and densities of benthic macrofauna were } \\
\text { seasonally recorded in mudflats, aiming to evaluate the relationship } \\
\text { between the biota and hydrological scenarios of the Patos Lagoon } \\
\text { estuary. }\end{array}$ \\
\hline VI & $\begin{array}{l}\text { Ecology of the pink-shrimp Penaeus paulensis in Patos Lagoon estuary } \\
\text { (https://doi.org/10.15468/ovayhc) (Dumont, 2020) }\end{array}$ & $\begin{array}{l}\text { This data provides unique long-term information enabling the } \\
\text { evaluation of natural and anthropic impacts in the estuarine and coastal } \\
\text { region in southern Brazil, for an intensively exploited fishery } \\
\text { resource, such as the pink-shrimp Penaeus paulensis. }\end{array}$ \\
\hline VII & $\begin{array}{l}\text { Species composition and abundance patterns of fish assemblages at } \\
\text { shallow waters of Patos Lagoon estuary } \\
\text { (https://doi.org/10.15468/kci8zb) (Vieira et al., 2020) }\end{array}$ & $\begin{array}{l}\text { Species composition, size structure, relative abundance and diversity } \\
\text { patterns of fish have been monitored in shallow waters }(<2 \mathrm{~m}) \text { aiming } \\
\text { to evaluate the relationship between the biota and hydrological } \\
\text { scenarios, climatic events and antropogenic causes. }\end{array}$ \\
\hline VIII & $\begin{array}{l}\text { Ecology of Lahille's bottlenose dolphin Tursiops truncatus gephyreus } \\
\text { in the Patos Lagoon estuary and adjacent marine coast } \\
\text { (https://doi.org/10.15468/4nh9ng) (Secchi et al., 2020) }\end{array}$ & $\begin{array}{l}\text { Tursiops truncatus gephyreus have been systematically and } \\
\text { intensively monitored in the Patos Lagoon estuary and adjacent } \\
\text { marine coast. This long-term surveys allowed estimating on the } \\
\text { distribution, abundance, reproductive and survival rates, genetic and } \\
\text { social structures, contamination load and detecting temporal and } \\
\text { gender-related variation in diet of the Lahille's bottlenose dolphin. }\end{array}$ \\
\hline
\end{tabular}

\subsection{Datasets structure}

375 All datasets are available as a Darwin Core Archive (DwC-A) and all fields were named compliant with Darwin Core Standard (DwC) (TDWG, 2015). The DwC offers a stable and flexible framework to store all fields available in original data sources. Each dataset is published as a Sampling event data being formatted using a star-scheme based on the OBIS-ENV-DATA format (De Pooter et al., 2017), which includes an Event Core (event sampling data), Occurrence (taxonomic data) and Extended Measurement-or-Fact (environmental variables and taxa abundances) (Fig. 3). 


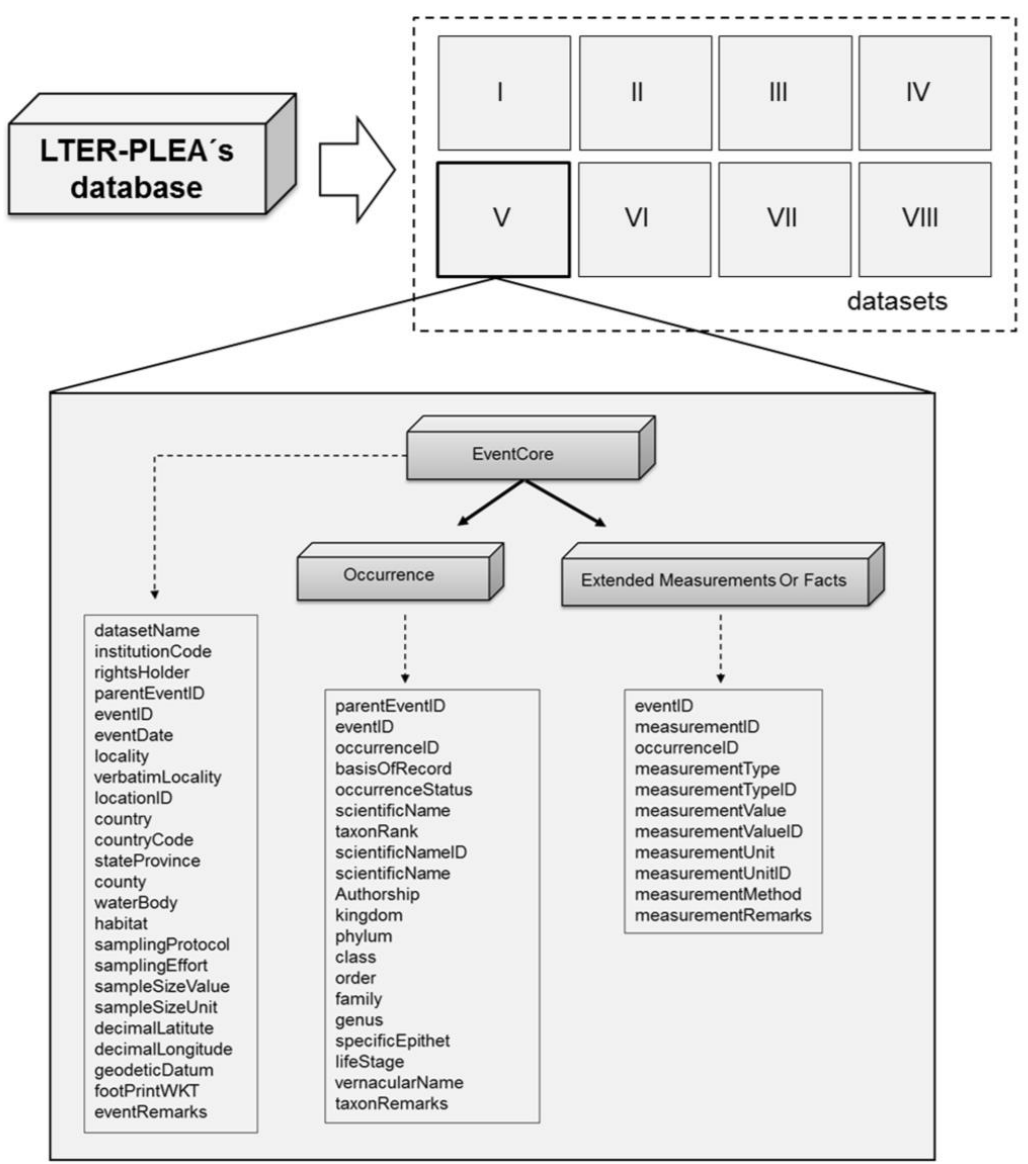

Figure 3: LTER-PLEA's dataset structure. LTER-PLEA's dataset structure based on the OBISENV-DATA format. Darwin Core terms (https://dwc.tdwg.org/terms/) used in each extension are described in the boxes. Dataset: I- Phytoplankton and water quality parameters in the Patos Lagoon estuary and adjacent marine coast; II- Continuous monitoring of the micro and mesozooplankton of the Patos Lagoon estuary and adjacent coastal area; III- Interannual variability of ichthyoplankton diversity in the Patos Lagoon estuary Southern Brazil; IV- Dynamics of submerged aquatic vegetation in the Patos Lagoon estuary; V- Temporal data series of benthic macrofauna abundance and composition from the Patos Lagoon estuary; VI- Ecology of the pink-shrimp Penaeus paulensis in Patos Lagoon estuary; VII- Species composition and abundance patterns of fish assemblages at shallow waters of Patos Lagoon estuary; VIII- Ecology of Lahille's bottlenose dolphin Tursiops truncatus gephyreus in the Patos Lagoon estuary and adjacent marine coast.

395 Each sampling event formed one row in the Event Core data table and was identified by an eventID code that is an unique identifier of each sampling event (something that occurs at a place and time) (TDWG, 2015) and was built according to the following information: (1) The standard code for the country (Brazil-Br), (2) project name, i.e., the source organization (i.e., in Portuguese: PELD-ELPA), (3) the identifier for the institution having custody of the information referred to in the record 400 (Universidade Federal de Rio Grande - FURG), (4) locality name (Patos Lagoon), (5) dataset name, (6) year, (7) month and (8) identifier of sampling station. 
The LTER-PLEA's database contains a total of 6,972 sampling event records unequally distributed across the research groups during the monitoring period (Fig. 4). Sampling events encompassed 106,155 taxa occurrences and 22,190 abiotic measurements (Fig. 5) in the Patos Lagoon estuary and

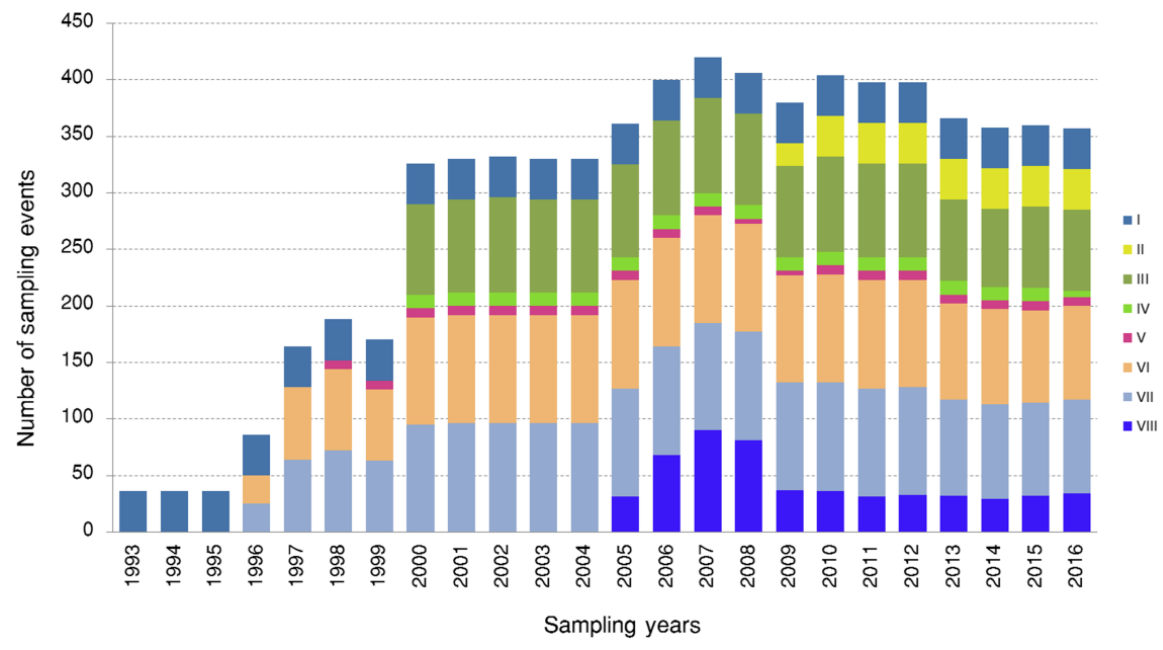

Figure 4: Number of sampling events for dataset (biota monitoring) in the Patos Lagoon estuary and adjacent marine coast from 1993 to 2016. Plot shows the number of sampling events collected at each year, for each dataset. Dataset: I- Phytoplankton and water quality parameters in the Patos Lagoon estuary and adjacent marine coast; II- Continuous monitoring of the micro and mesozooplankton of the Patos Lagoon estuary and adjacent coastal area; III- Interannual variability of ichthyoplankton diversity in the Patos Lagoon estuary Southern Brazil; IV- Dynamics of submerged aquatic vegetation in the Patos Lagoon estuary; V- Temporal data series of benthic macrofauna abundance and composition from the Patos Lagoon estuary; VI- Ecology of the pink-shrimp Penaeus paulensis in Patos Lagoon estuary; VII- Species composition and abundance patterns of fish assemblages at shallow waters of Patos Lagoon estuary; VIII- Ecology of Lahille's bottlenose dolphin Tursiops truncatus gephyreus in the Patos Lagoon estuary and adjacent marine coast. 


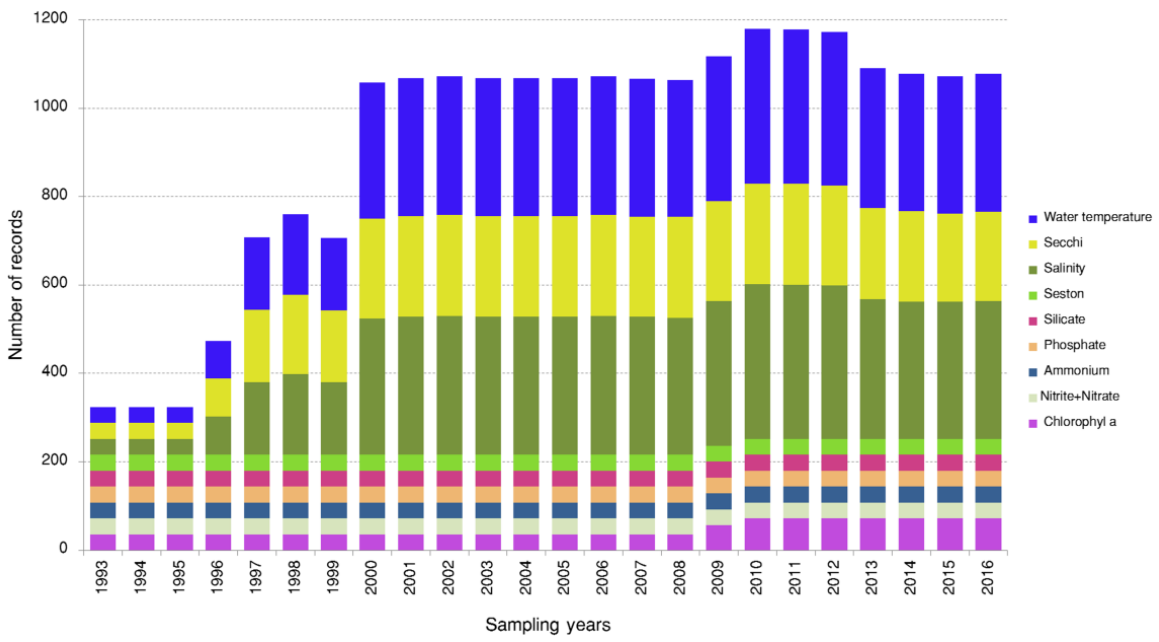

Figure 5: Abiotic records from the LTER-PLEA's database. Sampling events to measure water salinity, water temperature, water transparency, suspended particulate matter, chlorophyll-a, and dissolved inorganic nutrients in Patos Lagoon estuary and adjacent marine coast from 1993 to 2016.

\subsection{Taxonomic coverage}

General taxonomic coverage description: The eight datasets comprise the description of the occurrence of 21 Phyla, 30 Classes, 78 Orders, 142 Families, 232 Genera and about 275 Species from the five

Kingdoms: Bacteria, Protozoa, Chromista, Plantae and Animalia (appendix A).

\subsection{Datasets taxonomic coverage:}

\subsubsection{Phytoplankton (Dataset - I)}

435 Taxonomic ranks: Kingdoms: Bacteria, Chromista, Plantae and Protozoa.

Phyla: Charophyta, Chlorophyta, Ciliophora, Cryptophyta, Cyanobacteria, Euglenozoa, Myzozoa and Ochrophyta.

Class: Bacillariophyceae, Chlorophyceae, Conjugatophyceae, Cryptophyceae, Cyanophyceae, Dictyochophyceae, Dinophyceae, Euglenoidea, Litostomatea, Prasinophyceae, Pyramimonadophyceae,

Raphidophyceae, Trebouxiophyceae and Ulvophyceae.

Orders: Aulacoseirales, Bacillariales, Chaetocerotanae incertae sedis, Chattonellales, Chroococcales, Coscinodiscales, Cyclotrichiida, Cymatosirales, Dictyochales, Dinophysiales, Eutreptiida, Fragilariales, Gonyaulacales, Gymnodiniales, Halosphaerales, Hemiaulales, Leptocylindrales, Lithodesmiales, Melosirales, Naviculales, Noctilucales, Nostocales, Oscillatoriales, Paraliales, Peridiniales, 445 Prorocentrales, Rhizosoleniales, Surirellales, Synechococcales, Thalassionematales, Thalassiosirales, Triceratiales and Ulotrichales.

Families: Aphanizomenonaceae, Aphanothecaceae, Aulacoseiraceae, Bacillariaceae, Ceratiaceae, Chaetocerotaceae, Coscinodiscaceae, Cymatosiraceae, Dictyochaceae, Dinophysiaceae, 
Diploneidaceae, Entomoneidaceae, Eutreptiaceae, Fragilariaceae, Gloeotilaceae, Gonyaulacaceae,

Melosiraceae, Merismopediaceae, Mesodiniidae, Microcystaceae, Naviculaceae, Noctilucaceae, Nostocaceae, Paraliaceae, Peridiniaceae, Pleurosigmataceae, Polykrikaceae, Prorocentraceae, Protoperidiniaceae, Pseudanabaenaceae, Pterospermataceae, Rhizosoleniaceae, Skeletonemaceae, Stephanopyxidaceae, Surirellaceae, Thalassionemataceae, Thalassiosiraceae and Triceratiaceae.

Genus: Akashiwo, Alexandrium, Amphidinium, Aphanocapsa, Asterionellopsis, Aulacoseira, Bacillaria, Bacteriastrum, Binuclearia, Campylosira, Cerataulina, Ceratoneis, Chaetoceros, Coscinodiscus, Dactyliosolen, Detonula, Dictyocha, Dinophysis, Diploneis, Ditylum, Entomoneis, Guinardia, Gyrodinium, Gyrosigma, Hemiaulus, Leptocylindrus, Leptolyngbya, Lithodesmium, Melosira, Mesodinium, Meuniera, Microcystis, Neocalyptrella, Nitzschia, Noctiluca, Paralia, Peridinium, Planktolyngbya, Pleurosigma, Polykrikos, Proboscia, Prorocentrum, Protoperidinium, Pseudo-nitzschia, Pseudosolenia, Pterosperma, Raphidiopsis, Rhizosolenia, Scrippsiella, Skeletonema, Stephanopyxis, Surirella, Synedra, Thalassionema, Thalassiosira, Torodinium, Trieres and Tripos.

Subgenus: Chaetoceros (Hyalochaeta) and Chaetoceros (Phaoceros).

Species: Akashiwo sanguínea, Alexandrium fraterculus, Asterionellopsis guyunusae, Aulacoseira granulata, Bacillaria paxillifera, Binuclearia lauterbornii, Campylosira cymbelliformis, Cerataulina bicornis, Ceratoneis closterium, Chaetoceros subtilis, Coscinodiscus wailesii, Dactyliosolen fragilissimus, Detonula pumila, Dictyocha fibula, Dinophysis acuminata, Dinophysis caudata, Ditylum brightwellii, Guinardia delicatula, Guinardia flaccida, Gyrodinium fusus, Leptocylindrus danicus, Leptocylindrus minimus, Melosira moniliformis, Meuniera membranacea, Neocalyptrella robusta,

Noctiluca scintillans, Paralia sulcata, Peridinium quinquecorne, Polykrikos schwartzii, Prorocentrum compressum, Prorocentrum cordatum, Prorocentrum micans, Prorocentrum scutellum, Pseudosolenia calcar-avis, Rhizosolenia setigera, Scrippsiella trochoidea, Skeletonema costatum, Skeletonema tropicum, Stephanopyxis turris, Thalassionema nitzschioides, Trieres chinensis, Trieres mobiliensis, Tripos furca and Tripos muelleri.

\subsubsection{Micro and mesozooplankton (Dataset - II)}

Taxonomic ranks: Kingdom Animalia.

Phyla: Annelida, Arthropoda, Chaetognatha, Chordata, Cnidaria, Ctenophora, Echinodermata, Mollusca, Phoronida and Rotifera.

480 Class: Appendicularia, Bivalvia, Branchiopoda, Gastropoda, Hexanauplia, Hydrozoa, Ichthyostraca, Malacostraca, Ostracoda, Polychaeta, Sagittoidea and Thaliacea.

Orders: Amphipoda, Anomopoda, Aphragmophora, Arguloida, Calanoida, Copelata, Ctenopoda, Cumacea, Cyclopoida, Decapoda, Euphausiacea, Harpacticoida, Isopoda, Mysida, Onychopoda, Salpida, Sessilia, Siphonophorae, Siphonostomatoida and Tanaidacea.

485 Families: Acartiidae, Balanidae, Bosminidae, Calanidae, Centropagidae, Chydoridae, Clausocalanidae, Corycaeidae, Cyclopidae, Daphniidae, Diaptomidae, Ditrichocorycaeus, Ectinosomatidae, Ergasilidae, Eurycercidae, Heterorhabdidae, Ilyocryptidae, Kalliapseudidae, Lubbockiidae, Luciferidae, Macrothricidae, Miraciidae, Moinidae, Oikopleuridae, Oithonidae, Oncaeidae, Onychocorycaeus, 
Paracalanidae, Peltidiidae, Podonidae, Pontellidae, Pseudodiaptomidae, Sagittidae, Sapphirinidae,

Scolecitrichidae, Sididae, Subeucalanidae, Tachidiidae and Temoridae.

Genus: Acanthocyclops, Acartia, Alona, Amphibalanus, Argyrodiaptomus, Belzebub, Biapertura, Boeckella, Bosmina, Bosminopsis, Calanoides, Calanus, Camptocercus, Centropages, Ceriodaphnia, Chydorus, Clausocalanus, Clytemnestra, Corycaeus, Ctenocalanus, Daphnia, Diaphanosoma, Ephemeroporus, Ergasilus, Eucyclops, Euryalona, Euterpina, Evadne, Flaccisagitta, Halicyclops, Heterorhabdus, Ilyocryptus, Kalliapseudes, Labidocera, Lubbockia, Macrosetella, Macrothrix, Mecynocera, Mesocyclops, Metacyclops, Microsetella, Moina, Nannocalanus, Notoalona, Notodiaptomus, Oikopleura, Oithona, Oncaea, Paracalanus, Parasagitta, Parvocalanus, Penilia, Pleopis, Podon, Pontellopsis, Pseudevadne, Pseudodiaptomus, Pseudosagitta, Pseudosida, Sapphirina, Scolecithrix, Simocephalus, Subeucalanus, Temora and Undinula.

500 Species: Acanthocyclops robustus robustos, Acartia (Acanthacartia) tonsa, Acartia (Odontacartia) lilljeborgi, Alona costata, Alona monacantha, Amphibalanus improvisus, Argyrodiaptomus denticulatus, Biapertura affinis, Boeckella bergi, Bosmina (Bosmina) longirostris, Bosminopsis deitersi, Calanoides carinatus, Camptocercus australis, Centropages furcatus, Ceriodaphnia cornuta, Ceriodaphnia dubia, Chydorus eurynotus, Chydorus parvireticulatus, Chydorus sphaericus,

Clausocalanus furcatus, Clausocalanus parapergens, Corycaeus speciosus, Ctenocalanus citer, Ctenocalanus vanus, Daphnia (Daphnia) ambigua, Diaphanosoma brachyurum, Diaphanosoma brevireme, Diaphanosoma fluviatile, Diaphanosoma spinulosum, Ditrichocorycaeus amazonicus, Eucyclops ensifer, Euryalona orientalis, Euterpina acutifrons, Evadne nordmanni, Flaccisagitta enflata, Goniopsyllus rostratus, Heterorhabdus papilliger, Ilyocryptus spinifer, Labidocera fluviatilis, Lubbockia squillimana, Macrosetella gracilis, Macrothrix spinosa, Mecynocera clausi, Mesocyclops longisetus longisetus, Metacyclops mendocinus mendocinus, Microsetella norvegica, Microsetella rosea, Moina micrura, Moina minuta, Nannocalanus minor, Notoalona sculpta, Notodiaptomus incompositus, Oithona nana, Oithona oswaldocruzi, Oithona plumifera, Oithona similis, Oithona simplex, Oncaea curvata, Oncaea lacinia, Oncaea mediterranea, Oncaea venusta, Oncaea waldemari, Onychocorycaeus giesbrechti, Paracalanus aculeatus, Paracalanus indicus, Paracalanus parvus, Paracalanus quasimodo, Parasagitta tenuis, Parvocalanus crassirostris, Penilia avirostris, Pleopis polyphemoides, Pleopis schmackeri, Pontellopsis brevis, Pseudevadne tergestina, Pseudodiaptomus richardi, Pseudosagitta lyra, Pseudosida bidentata, Scolecithrix danae, Simocephalus latirostris, Simocephalus serrulatus, Simocephalus vetulus, Subeucalanus pileatus, Temora stylifera, Temora turbinata and Undinula vulgaris.

\subsubsection{Ichthyoplankton (Dataset - III)}

Taxonomic ranks: Kingdom Animalia.

Phylum: Chordata.

Class: Actinopterygii.

Orders: Anguilliformes, Atheriniformes, Beloniformes, Characiformes, Clupeiformes, Cyprinodontiformes, Elopiformes, Gobiesociformes, Perciformes, Pleuronectiformes, Siluriformes and Syngnathiformes. 
Families: Achiridae, Anablepidae, Atherinidae, Atherinopsidae, Blenniidae, Carangidae, Characidae,

Clupeidae, Engraulidae, Gerreidae, Gobiesocidae, Gobiidae, Hemiramphidae, Mugilidae, Paralichthyidae, Pimelodidae, Poeciliidae, Sciaenidae, Stromateidae, Syngnathidae and Trichiuridae.

Genus: Anchoa, Atherinella, Blennius, Brevoortia, Catathyridium, Cynoscion, Engraulis, Eucinostomus, Gobiesox, Gobionellus, Gobiosoma, Hyporhamphus, Jenynsia, Lycengraulis, Macrodon, Menticirrhus, Micropogonias, Mugil, Odontesthes, Paralichthys, Paralonchurus,

535 Parapimelodus, Parona, Peprilus, Poecilia, Ramnogaster, Syngnathus, Trachinotus and Trichiurus.

Species: Anchoa marinii, Brevoortia pectinata, Catathyridium garmani, Catathyridium jenynsii, Engraulis anchoita, Eucinostomus gula, Eucinostomus melanopterus, Gobiesox strumosus, Gobionellus oceanicus, Gobiosoma parri, Hyporhamphus roberti, Lycengraulis grossidens, Macrodon atricauda, Menticirrhus americanus, Micropogonias furnieri, Mugil curema, Mugil liza, Paralichthys

540 orbignyanus, Paralonchurus brasiliensis, Parapimelodus nigribarbis, Parona signata, Poecilia vivipara, Ramnagaster arcuata, Syngnathus folletti, Trachinotus goodei and Trichiurus lepturus.

\subsubsection{Submerged aquatic vegetation (Dataset - IV)}

Taxonomic ranks: Kingdom Plantae.

545 Subkingdoms: Biliphyta and Viridiplantae.

Division: Chlorophyta, Rhodophyta and Tracheophyta.

Class: Florideophyceae, Magnoliopsida and Ulvophyceae.

Orders: Acrochaetiales, Alismatales, Ceramiales, Cladophorales and Ulvales.

Families: Acrochaetiaceae, Cladophoraceae, Rhodomelaceae, Ruppiaceae and Ulvaceae.

550 Genus: Acrochaetium, Chaetomorpha, Cladophora, Polysiphonia, Rhizoclonium, Ruppia and Ulva.

Species: Ruppia maritima $($ common name = widgeon grass), Chaetomorpha antennina, Chaetomorpha sp., Cladophora spp., Rhizoclonium riparium, Ulva clathrata, Ulva compressa, Ulva intestinalis, Ulva ramulosa and Ulva sp.

\section{$555 \quad$ 2.7.5 Benthic macrofauna (Dataset - V)}

Taxonomic ranks: Kingdom Animalia.

Phyla: Annelida, Arthropoda and Mollusca.

Class: Bivalvia, Gastropoda, Malacostraca and Polychaeta.

Orders: Cumacea, Isopoda, Littorinimorpha, Myida, Phyllodocida and Tanaidacea.

560 Families: Capitellidae, Cochliopidae, Corbulidae, Diastylidae, Hyssuridae, Kalliapseudidae, Munnidae, Nephtyidae, Nereididae, Sphaeromatidae and Tanaididae.

Genus: Alitta, Diastylis, Erodona, Heleobia, Heteromastus, Kupellonura, Laeonereis, Monokalliapseudes, Nephtys, Sinelobus, Sphaeromopsis and Uromunna.

Species: Alitta succinea, Diastylis sympterygiae, Erodona mactroides, Heleobia australis, Heleobia

charruana, Heteromastus similis, Laeonereis culveri, Monokalliapseudes schubarti, Nephtys fluviatilis,

Sinelobus stanfordi, Sphaeromopsis mourei and Uromunna peterseni. 
Class: Malacostraca.

Order: Decapoda.

Family: Penaeidae.

Genus: Penaeus.

575 Species: Penaeus paulensis.

Common name: pink-shrimp.

\subsubsection{Fish assemblages (Dataset - VII)}

Taxonomic ranks: Kingdom Animalia.

Phylum: Chordata.

Class: Actinopterygii.

Orders: Albuliformes, Anguilliformes, Atheriniformes, Batrachoidiformes, Beloniformes, Characiformes, Clupeiformes, Cyprinodontiformes, Elopiformes, Gobiesociformes, Perciformes, Pleuronectiformes, Scorpaeniformes, Siluriformes, Syngnathiformes and Tetraodontiformes.

585 Families: Achiridae, Albulidae, Anablepidae, Ariidae, Atherinidae, Atherinopsidae, Batrachoididae, Callichthyidae, Carangidae, Characidae, Cichlidae, Clupeidae, Curimatidae, Cynoglossidae, Elopidae, Engraulidae, Erythrinidae, Gerreidae, Gobiesocidae, Gobiidae, Haemulidae, Hemiramphidae, Heptapteridae, Loricariidae, Monacanthidae, Mugilidae, Ophichthidae, Paralichthyidae, Percophidae, Pimelodidae, Pleuronectidae, Poeciliidae, Pomacentridae, Pomatomidae, Sciaenidae, Serranidae,

Syngnathidae, Tetraodontidae, Trichiuridae and Triglidae.

Genus: Abudefduf, Albula, Anchoa, Astyanax, Atherinella, Bathygobius, Brevoortia, Bryconamericus, Caranx, Catathyridium, Charax, Cheirodon, Chloroscombrus, Cichlasoma, Citharichthys, Cnesterodon, Corydoras, Crenicichla, Ctenogobius, Cyanocharax, Cynoscion, Cyphocharax, Diapterus, Elops, Engraulis, Epinephelus, Eucinostomus, Genidens, Geophagus, Gobiesox, Gobionellus,

595 Gymnogeophagus, Harengula, Hemiramphus, Hippocampus, Hoplias, Hyphessobrycon, Hyporhamphus, Jenynsia, Lagocephalus, Loricariichthys, Lycengraulis, Macrodon, Macropsobrycon, Menticirrhus, Micropogonias, Mugil, Odontesthes, Oligoplites, Oligosarcus, Oncopterus, Ophichthus, Opisthonema, Orthopristis, Paralichthys, Paralonchurus, Parapimelodus, Percophis, Phalloceros, Phalloptychus, Phalloptychus, Pimelodella, Pimelodus, Platanichthys, Poecilia, Pogonias, Pomadasys,

600 Pomatomus, Porichthys, Prionotus, Ramnogaster, Rhamdia, Sardinella, Selene, Stellifer, Stephanolepis, Symphurus, Syngnathus, Trachinotus, Trichiurus, Ulaema and Umbrina.

Species: Abudefduf saxatilis, Albula vulpes, Amoya gracilis, Anchoa marinii, Astyanax dissensus, Astyanax eigenmanniorum, Astyanax fasciatus, Astyanax henseli, Astyanax lacustris, Atherinella brasiliensis, Bathygobius soporator, Brevoortia pectinata, Bryconamericus iheringii, Caranx hippos,

605 Caranx latus, Catathyridium garmani, Charax stenopterus, Cheirodon ibicuhiensis, Cheirodon interruptus, Chloroscombrus chrysurus, Cichlasoma portalegrense, Citharichthys spilopterus, Cnesterodon decemmaculatus, Corydoras paleatus, Crenicichla lepidota, Ctenogobius shufeldti, Cyanocharax alburnus, Cynoscion leiarchus, Cynoscion striatus, Cyphocharax saladensis, 
Cyphocharax voga, Diapterus rhombeus, Elops saurus, Engraulis anchoita, Eucinostomus argenteus, planifrons, Geophagus brasiliensis, Gobiesox strumosus, Gobionellus oceanicus, Gymnogeophagus gymnogenys, Harengula clupeola, Hemiramphus brasiliensis, Hippocampus patagonicus, Hoplias malabaricus, Hyphessobrycon anisitsi, Hyphessobrycon bifasciatus, Hyphessobrycon boulengeri, Hyphessobrycon igneus, Hyphessobrycon luetkenii, Hyphessobrycon meridionalis, Hyphessobrycon reticulatus, Hyphessobrycon togoi, Hyporhamphus unifasciatus, Jenynsia multidentata, Lagocephalus laevigatus, Loricariichthys anus, Lycengraulis grossidens, Macrodon ancylodon, Macrodon atricauda, Macropsobrycon uruguayanae, Menticirrhus americanus, Menticirrhus littoralis, Micropogonias furnieri, Mugil brevirostris, Mugil curema, Mugil liza, Odontesthes argentinensis, Odontesthes bonariensis, Odontesthes perugiae, Oligoplites saliens, Oligoplites saurus, Oligosarcus jenynsii, Oligosarcus robustus, Oncopterus darwinii, Ophichthus gomesii, Opisthonema oglinum, Orthopristis ruber, Paralichthys orbignyanus, Paralonchurus brasiliensis, Parapimelodus nigribarbis, Percophis brasiliensis, Phalloceros caudimaculatus, Phalloptychus eigenmanni, Phalloptychus januarius, Pimelodella australis, Pimelodus maculatus, Platanichthys platana, Poecilia vivipara, Pogonias courbina, Pomadasys corvinaeformis, Pomatomus saltatrix, Porichthys porosissimus, Prionotus punctatus, Ramnogaster arcuata, Rhamdia quelen, Sardinella brasiliensis, Selene setapinnis, Selene vomer, Stellifer brasiliensis, Stellifer rastrifer, Stellifer stellifer, Stephanolepis hispidus, Stephanolepis setifer, Symphurus jenynsi, Syngnathus folletti, Trachinotus carolinus, Trachinotus falcatus, Trachinotus goodei, Trachinotus marginatus, Trichiurus lepturus, Ulaema lefroyi and Umbrina canosai.

\subsubsection{Lahille's bottlenose dolphin Tursiops truncatus gephyreus (Dataset - VIII)}

Taxonomic ranks: Kingdom Animalia.

Phylum: Chordata.

Class: Mammalia.

635 Order: Cetartiodactyla.

Family: Delphinidae.

Genus: Tursiops.

Species: Tursiops truncatus gephyreus

Common name: Lahille's bottlenose dolphins.

\subsection{Technical validation}

All datasets have reliable sampling properties (same sampling methodology over time), have been thoroughly checked, have broad temporal and taxonomic coverage, and are ready-to-use for analyses (accompanied with metadata information). The data management, including data validation process consisted of (i) data acquisition and ecological validation, (ii) taxonomic validation and (iii) structural validation:

(i) All data collection and ecological validation steps were carried out by the researchers responsible for the datasets (see Quality Assurance and Control in Sect 2.3). 
(ii) Taxonomic validation: Taxonomic nomenclature control was performed through the taxon match tool of the World Register of Marine Species (WoRMS, 2021), an authoritative and comprehensive list of marine organisms' taxonomy edited and reviewed by an international team of more than 240 taxonomic editors world-wide. Every species has a unique identifier known as Life Sciences Identifier (LSID), a persistent and globally unique. This identifier links the species name to an internationally accepted standardized name and associated taxonomic information, and also redirects to the most accurate information on the species taxonomy, (e.g. accepted names and synonyms).

(iii) Structural validation: Prior to publication, all datasets technical information's have been individually reviewed regarding the use of the DwC terms and taxonomic validity during upload in the Integrated Publishing Toolkit (IPT) provided by the SiBBr and subsequent GBIF registration (datasets were validated by the tool Data Validator available from GBIF). The Darwin Core was standardized according to the practices recommended by the TDWG guidelines (https://dwc.tdwg.org/terms/). Sampling dates formatted according to the ISO 8601 standard (i.e., YYYY-MM-DD). All files are available in Unicode (UTF-8) format.

\section{Data availability}

665 The LTER-PLEA's database policy follows the best practices of open data principles by releasing validated datasets on primary biodiversity and associate environmental data. The datasets were published in the GBIF repository through the Integrated Publishing Toolkit (IPT) provided by the Brazilian node $\mathrm{SiBBr}$ and can be accessed in the GBIF repository (Table 3). This publication refers to the most recent dataset published in the IPT. Monitoring is currently still being carried out and the database will be updated and published every four years. All datasets presented here are identified by unique persistent identifiers such as Digital Object Identifiers (DOIs) and are published under the Creative Commons Attribution-NonCommercial 4.0 International License (CC-BY-NC). Therefore, all datasets must be cited when used in scientific papers, presentations, reports or any other by-product generated by researchers; governmental agencies and the general public. Furthermore, is desirable that LTER-PLEA be included in the acknowledgements. When referring to the LTER-PLEA's database or sampling strategies and methodologies, please cite the present paper. The custodian of all the information collected is the Oceanography Institute of Federal University of Rio Grande.

\section{Potential use and Conclusions}

680 LTER-PLEA's is the first publicly available long-term database describing the abundance and composition of several components of planktonic, benthic, and pelagic biota from protists to mammals, associated with environmental data in an estuarine-coastal system of South America. The LTERPLEA's database has been the basis for several studies that investigate estuarine and coastal dynamics over time and has provided insights on the impacts of major anthropogenic and natural drivers, particularly the remote climate phenomena ENSO, across distinct taxonomic groups and trophic levels (Odebrecht et al., 2010; 2017).

The LTER-PLEA's database enabled the comprehension of the magnitude and drivers of short and long-term changes in the abundance and composition of phytoplankton (Haraguchi et al., 2015), 
submerged aquatic vegetation (Copertino and Seeliger, 2010; Lanari and Copertino, 2017), benthic macrofauna (Collin et al., 2007; 2010) micro and mesozooplankton assemblages (Muxagata et al., 2012; Teixeira-Amaral et al., 2017), the most relevant ichthyoplankton species (Bruno \& Muelbert, 2009; Costa et al., 2013), fish fauna (Garcia et al., 2001; 2003; 2004), pink shrimp and Lahille's bottlenose dolphin population parameters (Fruet et al., 2011; 2015; Genoves et al., 2018; 2020). All this information has enabled the understanding of the dynamics of ichthyoplankton transport and recruitment into the estuary (Franzen et al., 2019) and the influence of environmental dynamics on the health of fish larvae (Gouveia et al., 2015; Salvador and Muelbert, 2019), the influence of climatic and local factors on fish abundance, diversity and trophic organization (Garcia et al., 2003; 2012; 2017; Possamai et al., 2018), the evaluation of the secondary production of copepods and its main contributors (Muxagata et al., 2012; Teixeira-Amaral et al., 2017), occurrence of potentially harmful microalgae groups (e.g., cyanobacteria and dinoflagellates) (Haraguchi et al., 2015), diatom accumulation in surf zone influenced by drastic events like mud deposition freshwater output (Odebrecht et al., 2010; 2013), phase-shifts in the SAV (Copertino and Seeliger, 2010; Lanari and Copertino, 2017), the recognition of the main nursery grounds for commercial species (D'Incao, 1991; Haimovici and Cardoso, 2017), overfishing impacts through analysis of Lahille's bottlenose dolphin (Fruet et al., 2011; 2014; Secchi et al., 2017), assessments of the conservation status and adaptive capacity and resilience of estuarine and marine organisms to anthropogenic changes and global warming (Bernardino et al., 2015; Copertino et al., 2016), among other relevant ecological processes.

ILTER datasets have subsidized meta-analyses of multidecadal biodiversity trends, hence corroborating the importance of long-term monitoring programmes to offer insights on changes in natural systems (e.g., Pilotto et al., 2020). In general, long-term biodiversity data have been biased towards few taxonomic groups and lacking associate environmental data, hindering the understanding of the drivers of detected changes (Pilotto et al., 2020). Our database thus provides a comprehensive view on the biota's spatio-temporal dynamics and its environmental drivers in a subtropical coastal marine system in the Southwestern Atlantic Ocean. Considering the over-representation of temperate regions in estuarine biodiversity and functioning studies (e.g., Vieillard et al., 2020), it allows to test for generalizations of previous findings across distinct biogeographical areas.

LTER-PLEA is one of the 115 globally distributed Coastal and Marine ILTER Sites (ILTER-CMS), a network that provides several opportunities to the study and monitoring of these ecosystems. ILTERCMS constitutes an observation platform for the Global Ocean Observing System (GOOS) defined Essential Ocean Variables (EOVs) and several regional and global programs (Muelbert et al., 2019). Comparisons of our datasets obtained in the southern hemisphere with other estuaries worldwide, would contribute to broaden our understanding on the role of the distinct signals (human versus climatic) in the biodiversity and functioning of these ecosystems (Paerl et al., 2015).

Our datasets can also contribute to analyses of emergent environmental issues over large temporal scale and geographic areas such as harmful algal blooms (Lyons et al., 2014) and overfishing (Brett et al., 2020). On a global scale, LTER-PLEA's long-term data have already supplied data to analyses of range-shifts in species distributions and abundance driven by climate changes (Hastings et al., 2020). The environmental data such as water temperature and nutrient concentration time series may foster assessments of global warming and nutrient pollution in coastal marine systems. Despite the coastal 
730 nutrient pollution reported worldwide, little data is available for tropical and subtropical estuarine systems (Vieillard et al., 2020) and our data may help to fulfill this knowledge gap.

The sustainable use of ecosystem services can only be devised on a solid scientific basis (Carstensen, 2014). Thus, the information about the biological and physical properties of the system could be also used towards integrative, interdisciplinary, and transversal approach, which may better link estuary, coastal zone, and the ocean to its ecosystem services. Furthermore, such high-quality information adds to conservation, management and restoration efforts of coastal and estuarine ecosystems (Costa et al., 2016), contributing to recommendations for public policies, at local, national and global levels. 
https://doi.org/10.5194/essd-2021-353

Preprint. Discussion started: 3 November 2021

(c) Author(s) 2021. CC BY 4.0 License.

740 Appendix A - General taxonomic coverage of the LTER-PLEA's database.

\begin{tabular}{|c|c|c|c|c|c|c|c|}
\hline kingdom & Subkingdon & Phylum/Division & Class & Order & Family & Genus & Specie \\
\hline \multirow[t]{8}{*}{ Bacteria } & & Cyanobacteria & Cyanophyceae & Chroococcales & Aphanothecaceae & & \\
\hline & & & & Nostocales & $\begin{array}{l}\text { Microcystaceae } \\
\text { Aphanizomenonaceae }\end{array}$ & Microcystis & \\
\hline & & & & & Nostocaceae & Raphidiopsis & \\
\hline & & & & Oscillatoriales & & & \\
\hline & & & & Synechococcales & Leptolyngbyaceae & & \\
\hline & & & & & Merismopediaceae & Aphanocapsa & \\
\hline & & & & & Pseudanabaenaceae & Leptolyngbya & \\
\hline & & & & & & Planktolyngbya & \\
\hline Protozoa & & Euglenozoa & Euglenoidea & Eutreptiida & Eutreptiaceae & & \\
\hline \multirow[t]{55}{*}{ Chromista } & & Ciliophora & Litostomatea & Cyclotrichiida & Mesodiniidae & Mesodinium & \\
\hline & & $\begin{array}{l}\text { Cryptophyta } \\
\text { Myzozoa }\end{array}$ & $\begin{array}{l}\text { Cryptophyceae } \\
\text { Dinophyceae }\end{array}$ & Dinophysiales & Dinophysiaceae & Dinophysis & Dinophysis acuminata \\
\hline & & & & & (5) & & Dinophysis caudata \\
\hline & & & & Gonyaulacales & Ceratiaceae & Tripos & $\begin{array}{l}\text { Tripos furca } \\
\text { Tripos muelleri }\end{array}$ \\
\hline & & & & & Ostreopsidaceae & Alexandrium & Alexandrium fraterculus \\
\hline & & & & Gymnodiniales & Gymnodiniaceae & Akashiwo & Akashiwo sanguinea \\
\hline & & & & & & Amphidinium & \\
\hline & & & & & & Gyrodinium & Gyrodinium fusus \\
\hline & & & & & & Torodinium & \\
\hline & & & & & Polykrikaceae & Polykrikos & Polykrikos schwartzii \\
\hline & & & & Noctilucales & Noctilucaceae & Noctiluca & Noctiluca scintillans \\
\hline & & & & Peridiniales & Peridiniaceae & Peridinium & Peridinium quinquecorne \\
\hline & & & & & & Scrippsiella & Scrippsiella trochoidea \\
\hline & & & & & Protoperidiniaceae & Protoperidinium & \\
\hline & & & & Prorocentrales & Prorocentraceae & Prorocentrum & Prorocentrum compressum \\
\hline & & & & & & & Prorocentrum cordatum \\
\hline & & & & & & & Prorocentrum micans \\
\hline & & & & & & & Prorocentrum scutellum \\
\hline & & Ochrophyta & Bacillariophyceae & Aulacoseirales & Aulacoseiraceae & Aulacoseira & Aulacoseira granulata \\
\hline & & & & Bacillariales & Bacillariaceae & Bacillaria & Bacillaria paxillifera \\
\hline & & & & & & $\begin{array}{l}\text { Nitzschia } \\
\text { Pseudo-nitzschia }\end{array}$ & \\
\hline & & & & Chatocerotanae incertae sedis & Chaetocerotaceae & Bacteriastrum & \\
\hline & & & & & & Chaetoceros & Chaetoceros Hyalochaeta \\
\hline & & & & & & & $\begin{array}{l}\text { Chaetoceros Phaoceros } \\
\text { Chaetoceros subtilis }\end{array}$ \\
\hline & & & & Coscinodiscales & Coscinodiscaceae & Coscinodiscus & Coscinodiscus wailesii \\
\hline & & & & Cymatosirales & Cymatosiraceae & Campylosira & Campylosira cymbelliformis \\
\hline & & & & Fragilariales & Fragilariaceae & Asterionellopsis & Asterionellopsis guyunusae \\
\hline & & & & & & $\begin{array}{l}\text { Ceratoneis } \\
\text { Synedra }\end{array}$ & Ceratoneis closterium \\
\hline & & & & Hemiaulales & Hemiaulaceae & Cerataulina & Cerataulina bicornis \\
\hline & & & & Leptocylindrales & Leptocylindraceae & $\begin{array}{l}\text { Hemiaulus } \\
\text { Leptocylindrus }\end{array}$ & Leptocylindrus danicus \\
\hline & & & & teptor yimun ales & & & Leptocylindrus minimus \\
\hline & & & & Lithodesmiales & Lithodesmiaceae & $\begin{array}{l}\text { Ditylum } \\
\text { Lithodesmium }\end{array}$ & Ditylum brightwellii \\
\hline & & & & Melosirales & Melosiraceae & Melosira & Melosira moniliformis \\
\hline & & & & & Stephanopyxidaceae & Stephanopyxis & Stephanopyxis turris \\
\hline & & & & Naviculales & Diploneidaceae & Diploneis & \\
\hline & & & & & Naviculaceae & Meuniera & Meuniera membranacea \\
\hline & & & & & Pleurosigmataceae & Gyrosigma & \\
\hline & & & & Paraliales & Paraliaceae & $\begin{array}{l}\text { Pleurosigma } \\
\text { Paralia }\end{array}$ & Paralia sulcata \\
\hline & & & & Rhizosoleniales & Rhizosoleniaceae & Dactyliosolen & Dactyliosolen fragilissimus \\
\hline & & & & & & Guinardia & Guinardia delicatula \\
\hline & & & & & & & Guinardia flaccida \\
\hline & & & & & & Neocalyptrella & Neocalyptrella robusta \\
\hline & & & & & & $\begin{array}{l}\text { Proboscia } \\
\text { Pseudosolenia }\end{array}$ & Pseudosolenia calcar-avis \\
\hline & & & & & & Rhizosolenia & Rhizosolenia setigera \\
\hline & & & & Surirellales & Entomoneidaceae & Entomoneis & \\
\hline & & & & & Surirellaceae & Surirella & \\
\hline & & & & Thalassionematales & Thalassionemataceae & Thalassionema & Thalassionema nitzschioides \\
\hline & & & & Thalassiosirales & Skeletonemaceae & Detonula & Detonula pumila \\
\hline & & & & & & Skeletonema & Skeletonema costatum \\
\hline & & & & & & & Skeletonema tropicum \\
\hline & & & & & Thalassiosiraceae & Thalassiosira & \\
\hline & & & & Triceratiales & Triceratiaceae & Odontella & \\
\hline & & & & & & Trieres & Trieres mobiliensis \\
\hline & & Ochrophyta & Dictyochophyceae & Dictyochales & Dictyochaceae & Dictyocha & Dictyocha fibula \\
\hline & & & Raphidophyceae & Chattonellales & & & \\
\hline \multirow[t]{17}{*}{ Plantae } & Viridiplantae & $\begin{array}{l}\text { Charophyta } \\
\text { Chlorophyta }\end{array}$ & $\begin{array}{l}\text { Conjugatophyceae } \\
\text { Chlorophyceae }\end{array}$ & & & & \\
\hline & & Chlorophyta & Prasinophyceae & Halosphaerales & Pterospermataceae & Pterosperma & \\
\hline & & & & & Trebouxiophyceae & & \\
\hline & & & Pyramimonadophyceae & & & & \\
\hline & & & $\begin{array}{l}\text { Trebouxiophyceae } \\
\text { Ulvophyceae }\end{array}$ & Ulotrichales & & Binuclearia & Binuclearia lauterbornii \\
\hline & & & & Cladophorales & Cladophoraceae & Chaetomorpha & Chaetomorpha antennina \\
\hline & & & & & & & Chaetomorpha sp. \\
\hline & & & & & & Cladophora & Cladophora ssp \\
\hline & & & & & & Rhizoclonium & Rhizoclonium riparium \\
\hline & & & & Ulvales & Ulvaceae & Ulva & Ulva clathrata \\
\hline & & & & & & & Ulva compressa \\
\hline & & & & & & & Ulva intestinalis \\
\hline & & & & & & & Ulva ramulosa \\
\hline & & & & & & & Ulva $s p$ \\
\hline & & Tracheophyta & Magnoliopsida & Alismatales & Potamogetonaceae & Ruppia & Ruppia maritima \\
\hline & Biliphyta & Rhodophyta & Florideophyceae & Acrochaetiales & Acrochaetiaceae & Acrochaetium & \\
\hline & & & & Ceramiales & Rhodomelaceae & Polysiphonia & \\
\hline
\end{tabular}


https://doi.org/10.5194/essd-2021-353

Preprint. Discussion started: 3 November 2021

(c) Author(s) 2021. CC BY 4.0 License.

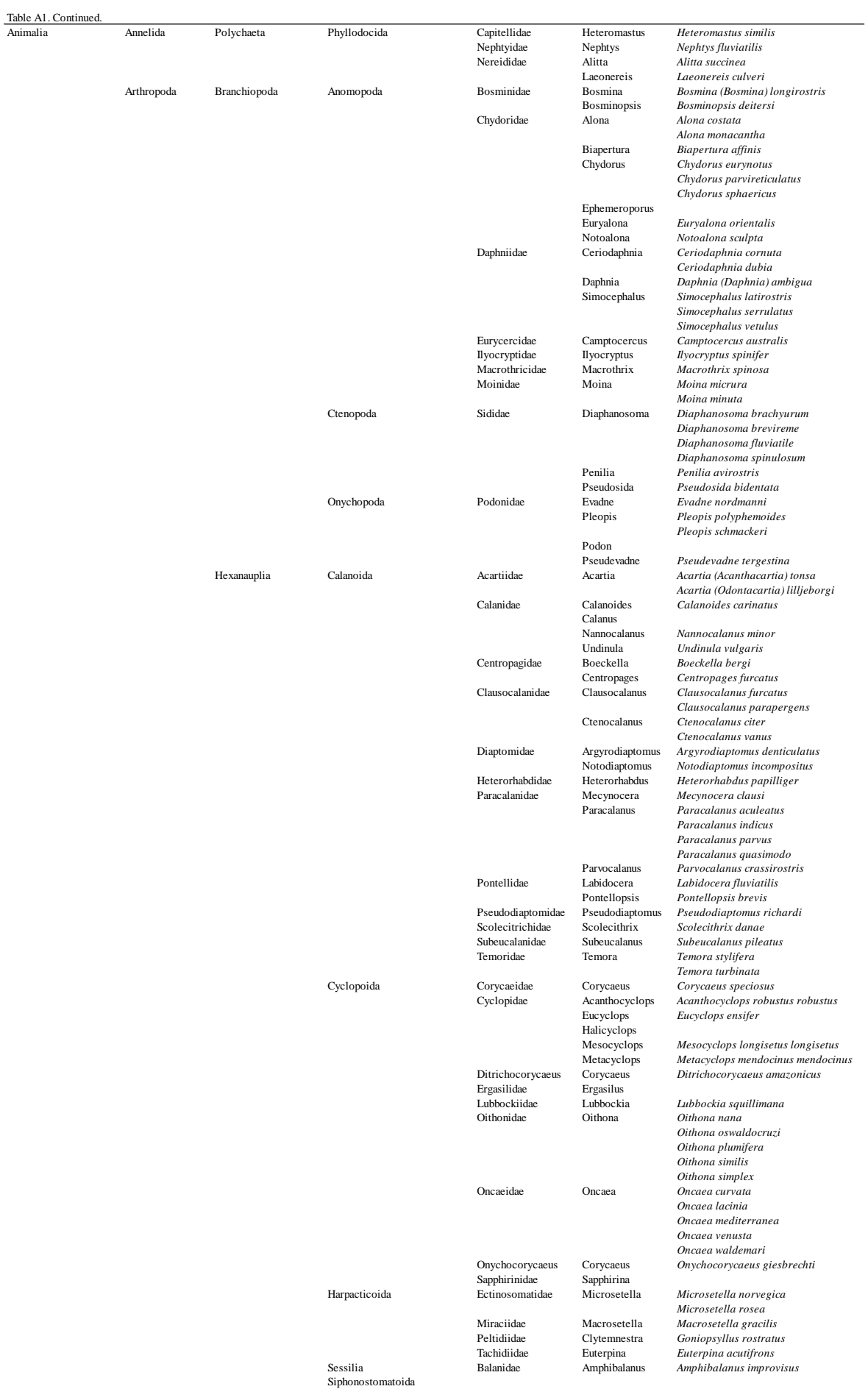


https://doi.org/10.5194/essd-2021-353

Preprint. Discussion started: 3 November 2021

(c) Author(s) 2021. CC BY 4.0 License.

745

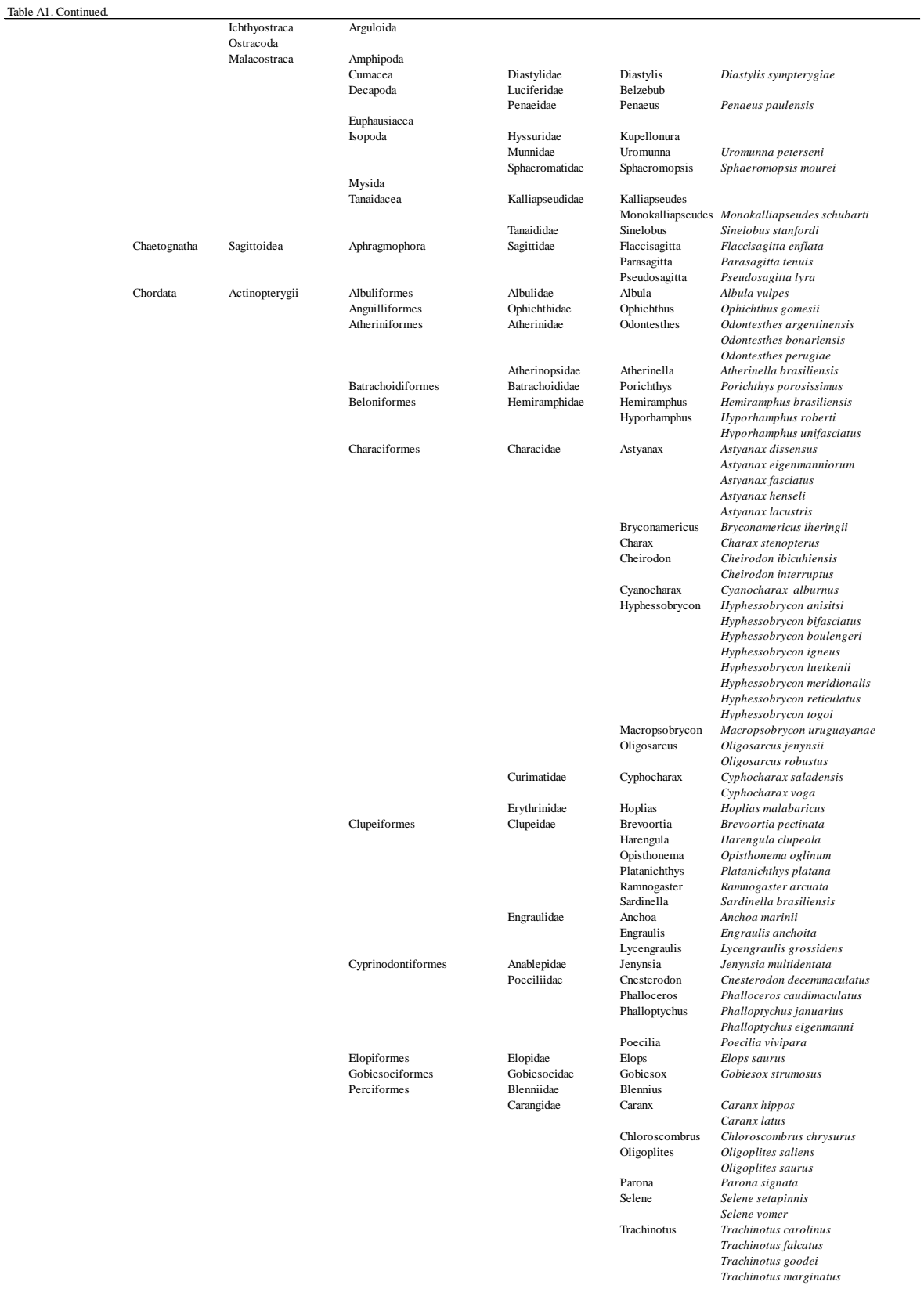




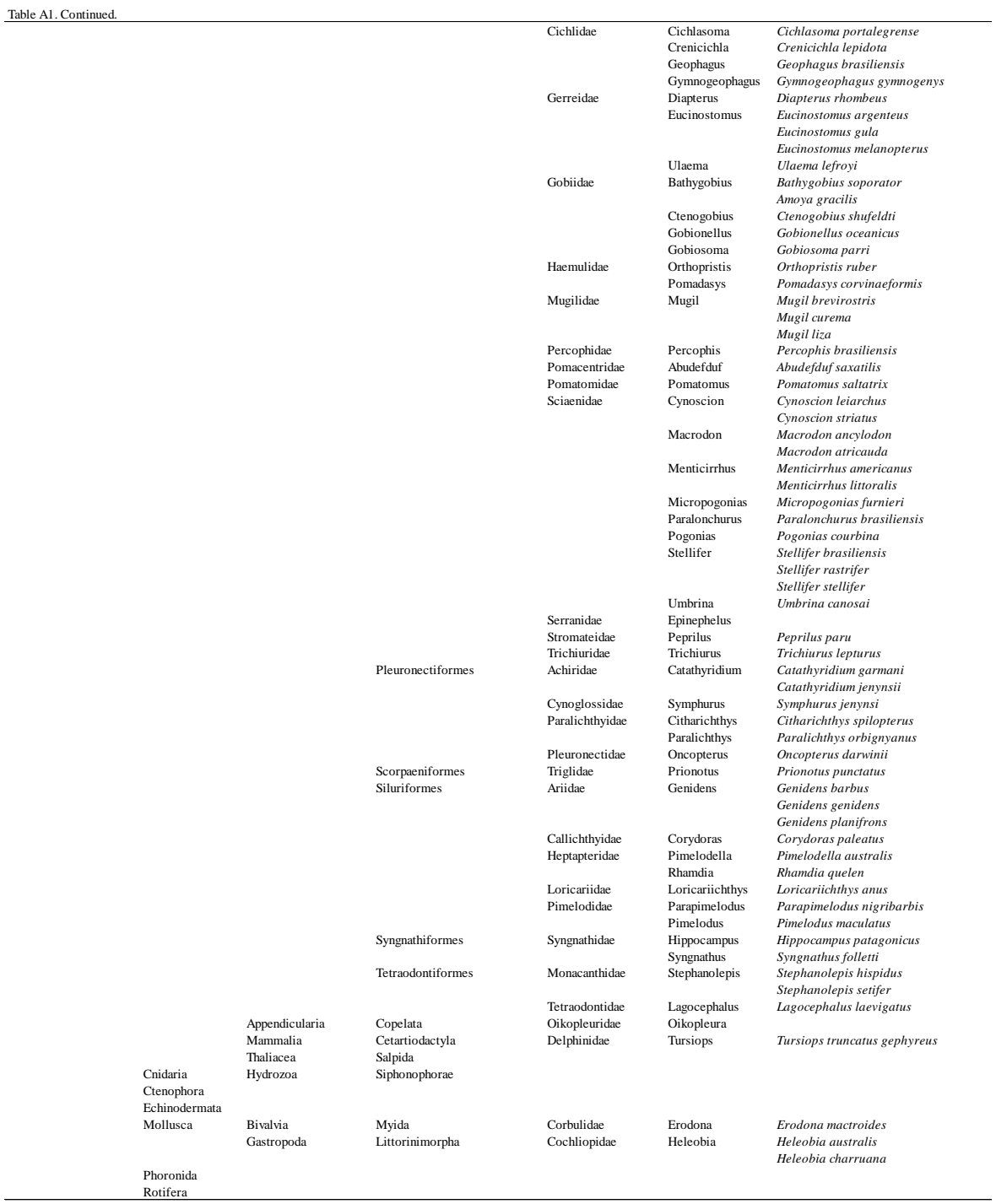

\section{Author contributions}

M.C. and M.L. conceived the data paper. V.M.L, M.L and M.C wrote the manuscript. M.C., E.M., P.C.A., J.H.M., F.C.D., E.R.S., J.P.V., A.M.G., A.C., C.O. coordinated the monitoring studies, provided metadata and data, reviewed the information on occurrence, abundance, taxonomic status of the species, and abiotic data. V.M.L. formatted the data and published the LTER-PLEA's database in GBIF. All authors commented on the paper and contributed to the quality check.

\section{Competing interests}

The authors declare that they have no conflict of interest. 


\section{Acknowledgements}

We would like to thank to the Dr. Ulrich Seeliger (emeritus professor), who was the creator of LTERPLEA, coordinating the program from 1999 to 2010. The Brazilian Long-Term Ecological Research Program has been supported by MCTI (Ministério de Ciência, Tecnologia e Inovação) and the Brazilian governmental funding agencies. The program also thanks to many laboratory technicians and undergraduate e graduate students that contributed to data sampling and organization.

\section{Financial support}

This research has been supported by Brazilian governmental funding agencies: CNPq (Conselho Nacional de Desenvolvimento Científico e Tecnológico, Process number: CNPQ Proc. 520188/98-5,

CNPQ Proc. 558230/2009-1, CNPQ Proc. 403805/2012-0, CNPq/CAPES/FAPs/BC - Fundo Newton/PELD no 15/2016, CNPq/MCTI/CONFAP-FAPs/PELD N² 21/2020, Proc.442206/2020-8), CAPES (Coordenação de Aperfeiçoamento Pessoal de Nivel Superior), and FAPERGS (Fundação de Amparo à Pesquisa do Rio Grande do Sul); the Newton Fund (British Council), and the Organization for the Conservation of South American Aquatic Mammals - YAQU PACHA e.V, Nuremberg Zoo.

\section{References}

Abreu, P. C., Bergesch, M., Proença, L. A., Garcia, C. A. E. and Odebrecht, C.: Short-and long-term chlorophyll a variability in the shallow microtidal Patos Lagoon estuary, Southern Brazil, Estuar. Coast., 33, 554-569, https://doi.org/10.1007/s12237-009-9181-9, 2010.

Abreu, P. C., Marangoni, J. and Odebrecht, C.: So close, so far: differences in long-term chlorophyll a variability in three nearby estuarine-coastal stations, Mar. Biol. Res., 13, 1-13, https://doi.org/10.1080/17451000.2016.1189081, 2016.

Amaral, A. C. Z. and Nonato, E. F. (Eds.): Annelida Polychaeta. Características glossário e chaves para famílias e gêneros da costa brasileira, Editora Unicamp, Brazil, 1996.

Balech, E.: Los dinoflagelados del Atlántico sudoccidental, Publ. Espec. Inst. Esp. Oceanogr., 1, 1-310, http://hdl.handle.net/10508/993, 1988.

Baumgarten, M. G. Z. and Niencheski, L. F. H.: A coluna sedimentar como reservatório e fonte de nutrientes em enseadas estuarinas, Trop. Oceanogr., 38, 88-155, https://doi.org/10.5914/tropocean.v38i1.5163, 2010.

Bergesch, M., Garcia, M. and Odebrecht, C.: Diversity and morphology of Skeletonema species in Southern Brazil, Southwestern Atlantic Ocean, J. Phycol., 45, 1348-1352, https://doi.org/10.1111/j.1529-8817.2009.00743.x, 2009.

Bernardino, A. F.; Netto, S. A.; Pagliosa, P. R.; Barros, F.; Christofoletti, R. A.; Rosa Filho, J. S.; Colling, A. and Lana, P. C.: Predicting ecological changes on benthic estuarine assemblages through decadal climate trends along Brazilian Marine Ecoregions, Estuar. Coast. Shelf Sci., 166, 74-82, https://doi.org/10.1016/j.ecss.2015.05.021, 2015.

Biodiversity Information Standards (TDWG): Darwin Core Terms: A quick reference guide, http://www.tdwg.org/, last access: October 2020. 
Björnberg, T. K. S.: Copepoda, in: Atlas del Zooplancton del Atlántico Sudoccidental y métodos de trabajo con el zooplancton marino, edited by: Boltovskoy, D., Pub. Esp. INIDEP, Mar del Plata, Argentina, 587-679, 1981.

Boltovskoy, D. (Ed.): Atlas Del Zooplancton Del Atlantico Sudoccidental Y Metodos De Trabajo Con El Zooplancton Marino, INIDEP, Mar del Plata, Argentina, 1981.

Boltovskoy, D. (Ed.): South Atlantic Zooplankton, Vol. 1-2, Backhuys Publishers, Leiden, 1999.

Bradford-Grieve, J.M.: Copepoda - Sub-Order: Calanoida - Family: Acartiidae - Genus: Acartia, in: Fiches d'Identification du Zooplancton, 1-19, 1999.

Brett, A.; Leape, J.; Abbott, M.; Sakaguchi, H.; Cao, L.; Chand, K.; Golbuu, Y.; Martin, T. J.; Mayorga, J. and Myksvoll, M. S.: Ocean data need a sea change to help navigate the warming world, Nature, 582, 181-183, https://doi.org/10.1038/d41586-020-01668-z, 2020.

Bruno, M. A. and Muelbert, J.H.: Distribuição espacial e variações temporais da abundância de ovos e larvas de Micropogonias furnieri no estuário da Lagoa dos Patos: registros históricos e forçantes ambientais, Atlântica, 31, 51-68, http://dx.doi.org/10.5088/atl.2009.31.1.51, 2009.

Buckup, L. and Bond-Buckup, G.: Os Crustáceos Do Rio Grande Do Sul, Editora da Universidade Federal do Rio Grande do Sul, Brazil, 1999.

Carstensen, J.: Need for monitoring and maintaining sustainable marine ecosystem services, Front. Mar. Sci., 1, 1-4, https://doi.org/10.3389/fmars.2014.00033, 2014.

Castello, J. P. and Möller Jr. O. O.: On the relationship between rainfall and shrimp production in the estuary of the Patos Lagoon (RS-Brazil), Atlântica, 3, 67-74, 1978.

Christian, R. R. and Mazzilli, S.: Defining the coast and sentinel ecosystems for coastal observations of global change, Hydrobiologia, 577, 55-70, https://doi.org/10.1007/978-1-4020-6008-3_6, 2007.

Colling, L. A. and Cavalca Bom, F.: Temporal data series of Benthic macrofauna abundance and composition from the Patos Lagoon estuary, GBIF, https://doi.org/10.15468/1soc2v, 2020.

Colling, L. A., Bemvenuti, C. E. and Gandra, M. S.: Seasonal variability on the structure of sublittoral macrozoobenthic association in the Patos Lagoon estuary, southern Brazil, Iheringia. Ser. Zool., 97, 257-262, https://doi.org/10.1590/S0073-47212007000300007, 2007.

Colling, L. A., Bemvenuti, C. E. and Pinotti, R. M.: Temporal variability of the bivalve Erodona mactroides BOSC, 1802 during and after the El Niño phenomenon (2002/2003) in a subtropical lagoon, southern Brazil, Acta. Limnol. Bras., 22, 410-423, https://doi.org/10.4322/actalb.2011.006, 2010.

CONCEA. Diretrizes da prática de eutanásia do CONCEA, Ministério da Ciência, Tecnologia e Inovação Conselho Nacional de Controle de Experimentação Animal, Brasil, 2013.

Copertino, M.: Dynamics of Submerged Aquatic Vegetation in the Patos Lagoon estuary, GBIF, https://doi.org/10.15468/bjzlnb, 2020.

Copertino, M. and Seeliger, U.: Habitats de Ruppia maritima e de macroalgas, in: O estuário da Lagoa dos Patos: Um Século de Transformações, edited by: Seeliger, U. and Odebrecht, C., Editora FURG, Brazil, 89-98, 2010.

Copertino, M. S.; Creed, J. C.; Magalhães, K. M.; Barros, K. D. S.; Lanari, M. D. O.; Arévalo, P. R. and Horta, P. A.: Monitoramento dos fundos vegetados submersos (pradarias submersas), in: Protocolos para o Monitoramento de Habitats Bentônicos Costeiros - Rede de Monitoramento de 

Oceanográfico da Universidade de São Paulo - IO/USP, Brazil, 2015.

Copertino, M. S.; Creed, J. C.; Lanari, M.; Magalhães, K.; Barros, K.; Lana, P. C.; Sordo, L. and Horta, P. A.: Seagrass and submerged aquatic vegetation (VAS) habitats off the coast of Brazil: state of knowledge, conservation and main threats, Braz. J. Oceanogr., 64, 53-80, https://doi.org/10.1590/S1679-875920161036064sp2, 2016.

Costa, M. D. and Muelbert, J. H.: Long-term assessment of temporal variability in spatial patterns of early life stages of fishes to facilitate estuarine conservation, Mar. Biol. Res., 13, 1-14, http://dx.doi.org/10.1080/17451000.2016.1213397, 2016.

Costa, M. D., Muelbert, J. H., Moraes, L. E., Vieira, J. P. and Castello, J. P.: Estuarine early life stage habitat occupancy patterns of whitemouth croaker Micropogonias furnieri (Desmarest, 1830) from the Patos Lagoon, Brazil, Fish. Res., 160, 77-84, http://dx.doi.org/10.1016/j.fishres.2013.10.025, 2013.

Costa, M. D., Possingham, H. P. and Muelbert, J. H.: Incorporating early life stages of fishes into estuarine spatial conservation planning, Aquat. Conserv., 26, 1013-1030, https://doi.org/10.1002/aqc.2584, 2016.

D’Incao, F.: Pesca e biologia de Penaeus paulensis na Lagoa dos Patos, RS, Atlântica., 13, 159-169, 1991.

De Pooter, D., Appeltans, W., Bailly, N., Bristol, S., Deneudt, K., Eliezer, M.; Fujioka, E.; Giorgetti, A.; Goldstein, P.; Lewis, M.; Lipizer, M.; Mackay,K.; Marin, M.; Moncoiffé, G.; Nikolopoulou, S.; Provoost, P.; Rauch, S.; Roubicek, A.; Torres, C.; van de Putte, A.; Vandepitte, L.; Vanhoorne, B.; Vinci, M.; Wambiji, N.; Watts, D.; Salas, E. K. and Hernandez, F.: Toward a new data standard for combined marine biological and environmental datasets-expanding OBIS beyond species occurrences, Biodivers. Data J., 5, 01-37, https://doi.org/10.3897/BDJ.5.e10989, 2017.

Doney, S. C. and Schimel, D.: Climate Change and Biogeochemical Impacts, eLS., https://doi.org/10.1002/9780470015902.a0003242.pub3, 2015.

Dreujou, E.; Carrier-Belleau, C.; Goldsmit, J.; Fiorentino, D.; Ben-Hamadou, R.; Muelbert, J. H.; Godbold, J. A.; Daigle, R. M. and Beauchesne, D.: Holistic Environmental Approaches and Aichi Biodiversity Targets: accomplishments and perspectives for marine ecosystems, Peer J., 8 , 01-22, http://doi.org/10.7717/peerj.8171, 2020.

Duffy, J. E.; Amaral-Zettler, L. A.; Fautin, D. G.; Paulay, G.; Rynearson, T. A.; Sosik, H. M. and Stachowicz, J. J.: Envisioning a marine biodiversity observation network, Bioscience., 63, 350 361, https://doi.org/10.1525/bio.2013.63.5.8, 2013.

Dumont, L. F. C.: Ecology of the pink-shrimp Penaeus paulensis in Patos Lagoon estuary, GBIF, https://doi.org/10.15468/ovayhc, 2020.

Fahay, M. P.: Guide to the early stages of marine fishes occurring in the western North Atlantic Ocean, Cape Hatteras to the southern Scotian Shelf, J. Northwest Atl. Fish. Sci., 4, 1-423, 1983.

Figueiredo, J. L. (Ed.): Manual De Peixes Marinhos Do Sudeste Do Brasil. I. Introdução. Cações, Raias E Quimeras, Museu de Zoologia da Universidade de São Paulo, Brazil, 1977. 
880 Figueiredo, J. L. and Menezes, N. A. (Eds.): Manual De Peixes Marinhos Do Sudeste Do Brasil. II. Teleostei (1), Museu de Zoologia da Universidade de São Paulo, Brazil, 1978.

Figueiredo, J. L. and Menezes, N. A. (Eds.): Manual De Peixes Marinhos Do Sudeste Do Brasil. III. Teleostei (2) Museu de Zoologia da Universidade de São Paulo, Brazil, 1980.

Figueiredo, J. L. and Menezes, N. A. (Eds.): Manual De Peixes Marinhos Do Sudeste Do Brasil. VI. Teleostei (5), Museu de Zoologia da Universidade de São Paulo, Brazil, 2000.

Fischer, L. G., Pereira, L. E. D. and Vieira, J. P. (Eds.): Peixes Estuarinos E Costeiros, Ecoscientia, Rio Grande, Brazil, 2004.

Franco, A. D. O. D. R., They, N. H., Canani, L. G. D. C., Maggioni, R. and Odebrecht, C.: Asterionellopsis tropicalis (Bacillariophyceae): a new tropical species found in diatom accumulations, J. Phycol., 52, 888-895, https://doi.org/10.1111/jpy.12435, 2016.

Franzen, M. O., Fernandes, E. H. L. and Muelbert, J. H.: Influence of wind events on the transport of early stages of Micropogonias furnieri (Desmarest, 1823) to a subtropical estuary, Lat. Am. J. Aquat. Res., 47, 536-546, http://dx.doi.org/10.3856/vol47-issue3-fulltext-15, 2019.

Froese, R. and Pauly, D.: FishBase, World Wide Web electronic publication, www.fishbase.org, last access: 2020.

Fruet, P. F., Secchi, E. R., Di Tullio, J. C. and Kinas, P. G.: Abundance of bottlenose dolphins, Tursiops truncatus (Cetacea: Delphinidae), inhabiting the Patos Lagoon estuary, southern Brazil: implications for conservation, Zoologia., 28, 23-30, https://doi.org/10.1590/S1984$46702011000100004,2011$.

Fruet, P. F.; Secchi, E. R.; Daura-Jorge, F.; Vermeulen, E.; Flores, P. A. C.; Simões-Lopes, P. C.; Genoves, R. C.; Laporta, P.; Di Tullio, J. C.; Freitas, T. R. O.; Rosa, L. D.; Valiati, V. H.; Beheregaray, L. B. and Möller, L. M.: Remarkably low genetic diversity and strong population structure in common bottlenose dolphins (Tursiops truncatus) from coastal waters of the Southwestern Atlantic Ocean, Conserv. Genet., 15, 879-895, https://doi.org/10.1007/s10592014-0586-z, 2014.

Fruet, P. F., Genoves, R. C., Möller, L. M., Botta, S. and Secchi, E. R.: Using mark-recapture and stranding data to estimate reproductive traits in female bottlenose dolphins (Tursiops truncatus) of the Southwestern Atlantic Ocean, Mar. Biol., 162, 661-673, https://doi.org/10.1007/s00227015-2613-0, 2015.

Garcia, A. M., Vieira, J. P. and Winemiller, K. O.: Dynamics of the shallow-water fish assemblage of the Patos Lagoon estuary (Brazil) during cold and warm ENSO episodes, J. Fish Biol., 59, 1218-1238, https://doi.org/10.1111/j.1095-8649.2001.tb00187.x, 2001.

Garcia, A. M., Vieira, J. P. and Winemiller, K. O.: Effects of 1997-1998 El Niño on the dynamics of the shallow-water fish assemblage of the Patos Lagoon Estuary (Brazil), Estuar. Coast. Shelf Sci., 57, 489-500, https://doi.org/10.1016/S0272-7714(02)00382-7, 2003.

Garcia, A. M., Vieira, J. P., Winemiller, K. O. and Grimm, A. M.: Comparison of 1982-1983 and 1997-1998 El Niño effects on the shallow-water fish assemblage of the Patos Lagoon estuary (Brazil), Estuaries., 27, 905-914, https://doi.org/10.1007/BF02803417, 2004. 
Garcia, A. M., Vieira, J. P., Winemiller, K. O., Moraes, L. E. and Paes, E. T.: Factoring scales of spatial and temporal variation in fish abundance in a subtropical estuary, Mar. Ecol. Prog., 461, 121135, https://doi.org/10.3354/meps09798, 2012.

Garcia, A. M. Winemiller, K. O.; Hoeinghaus, D. J.; Claudino, M. C.; Bastos, R.; Correa, F.; Huckembeck, S.; Vieira, J.; Loebmann, D.; Abreu, P.C. and Ducatti, C.: Hydrologic pulsing promotes spatial connectivity and food web subsidies in a subtropical coastal ecosystem. Mar. Ecol. Prog., 567, 17-28, https://doi.org/10.3354/meps12060, 2017.

Garcia, M. and Odebrecht, C.: Chave dicotômica ilustrada para a identificação de espécies de Thalassiosira cleve (diatomácea) no estuário da Lagoa dos Patos e área costeira adjacente (Rio Grande do Sul, Brasil), Biota Neotrop., 9, 239-253, https://doi.org/10.1590/S1676$06032009000200023,2009$.

Genoves, R. C., Fruet, P. F., Di Tullio, J. C., Möller, L. M. and Secchi, E. R.: Spatiotemporal use predicts social partitioning of bottlenose dolphins with strong home range overlap, Ecol. Evol., 8, 12597-12614, https://doi.org/10.1002/ece3.4681, 2018.

Genoves, R. C.; Fruet, P. F.; Botta, S.; Beheregaray, L. B.; Möller, L. M. and Secchi, E. R.: Fine-scale genetic structure in Lahille's bottlenose dolphins (Tursiops truncatus gephyreus) is associated with social structure and feeding ecology, Mar. Biol., 167, 1-16, https://doi.org/10.1007/s00227019-3638-6, 2020.

Gouveia, G. R., Trindade, G. S., Nery, L. E. M. and Muelbert, J. H.: UVA and UVB penetration in the water column of a South West Atlantic warm temperate estuary and its effects on cells and fish larvae, Estuaries. Coasts., 38, 1147-1162, http://dx.doi.org/10.1007/s12237-015-9996-5, 2015.

Gray, J. S. and Elliott, M. (Eds.): Ecology of Marine Sediments, 2nd ed., Oxford: Oxford University Press., EUA, 2009.

Grimm, A. M., Ferraz, S. E. T. and Gomes, J.: Precipitation anomalies in Southern Brazil associated with El Niño and La Niña events, J. Clim., 11, 2863-2880, https://doi.org/10.1175/1520-0442, 1998.

Hagström, J. A., Granéli, E., Moreira, M. O. and Odebrecht, C.: Produção de ácido domóico e composição elementar de duas cepas multissérie de Pseudo-nitzschia, do NW e SW do Oceano Atlântico, crescendo em culturas quimiostáticas limitadas por fósforo ou nitrogênio, J. Plankton. Res., 33, 297-308, 2011.

Haimovici, M. and Cardoso, L. G.: Long-term changes in the fisheries in the Patos Lagoon estuary and adjacent coastal waters in Southern Brazil, Mar. Biol. Res., 13, 135-150, https://doi.org/10.1080/17451000.2016.1228978, 2017.

Haimovici, M., Castello, J. P. and Abdallah, P. R.: Desenvolvimento da pesca industrial sediada em Rio Grande: uma visão histórica sob a ótica de atores privilegiados, in: A pesca marinha e estuarina no Brasil: estudos de caso, edited by: Haimovici, M., Andriguetto, J. M. and Sunye, P. S., Editora da FURG, Brazil, 17-28, 2014.

Halpern, B. S.; Walbridge, S.; Selkoe, K. A.; Kappel, K. V.; Micheli, F.; D'agrosa, K.; Bruno, J. F.; Casey, K. S.; Ebert, C.; Fox, H. E.; Fujita, R.; Heinemann, D.; Lenihan, H. S.; Madin, E. M. P.; Perry, M. T.; Selig, E. R.; Spalding, M.; Steneck, R. and Watson, R.: A global map of human 
impact on marine ecosystems, Science., 319, 948-952, https://doi.org/10.1126/science.1149345, 2008.

Haraguchi, L., Carstensen, J., Abreu, P. C. and Odebrecht, C.: Long-term changes of the phytoplankton community and biomass in the subtropical shallow Patos Lagoon Estuary, Brazil, Estu. Coast. Shelf. Sci., 162, 76-87, doi: 10.1016/j.ecss.2015.03.007, 2015.

Hastings, R. A. Rutterford, L. A.; Freer, J. J.; Collins, R. A.; Simpson, S. D. and Genner, M. G.: Climate change drives pole ward increases and equator ward declines in marine species, Curr.Biol., 30, 1572-1577, https://doi.org/10.1016/j.cub.2020.02.043, 2020.

Hoppenrath, M., Elbrächter, M. and Drebes, G. (Eds.): Marine Phytoplankton, Kleine SenckenbergReihe, Band 49, Germany, 2009.

Kalikoski, D. C. and Vasconcellos, M.: Case study of the technical, socio-economic and environmental conditions of small-scale fisheries in the estuary of Patos Lagoon, Brazil: a methodology for assessment, FAO Fisheries and Aquaculture, Circular C1075I, 2012.

Kennish, M. J. and Paerl, H. W. (Eds.): Coastal Lagoons: Critical Habitats of Environmental Change, CRC Press., EUA, 2010.

Kjerfve, B.: Comparative oceanography of coastal lagoons, in: Estuarine variability, edited by: Wolfe, D. A., Academic Press, 63-81, 1986.

Lanari, M. and Copertino, M.: Drift macroalgae in the Patos Lagoon Estuary (southern Brazil): effects of climate, hydrology and wind action on the onset and magnitude of blooms, Mar. Biol. Res., 13, 36-47, https://doi.org/10.1080/17451000.2016.1225957, 2017.

Lanari, M., Claudino, M. C., Garcia, A. M. and Copertino, M.: Changes in the elemental (C, N) and isotopic $(\delta 13 \mathrm{C}, \delta 15 \mathrm{~N})$ composition of estuarine plants during diagenesis and implications for ecological studies, J. Exp. Mar. Biol. Ecol., 500, 46-54, https://doi.org/10.1016/j.jembe.2017.12.013, 2018.

Lang, W.H.: Larval development of shallow water barnacles of the carolinas (Cirripedia: Thoracica) with keys to naupliar stages, NOAA Technical Report NMFS, Circular 421, 1979.

Lang, W.H.: Cirripedia: balanomorph nauplii of the NW Atlantic shores, Fiche 163, Fiches d'Identification du Zooplancton, Scotland, 1980.

Lotze, H. K.; Lenihan, H. S.; Bourque, B. J.; Bradbury, R. H.; Cooke, R. G.; Kay, M. C.; Kidwell, S. M.; Kirby, M. X.; Peterson, C. H. and Jackson, J. B. C.: Depletion, degradation, and recovery potential of estuaries and coastal seas, Science., 312, 1806-1809, https://doi.org/10.1126/science.1128035, 2006.

Lyons, T. W., Reinhard, C. T. and Planavsky, N. J.: The rise of oxygen in Earth's early ocean and atmosphere, Nature., 506, 307-315, https://doi.org/10.1038/nature13068, 2014.

McLusky, D. S. and Elliott, M.: The Estuarine Ecosystem: Ecology, Threats and Management, OUP Oxford, EUA, 2004.

Menezes, N. A. and Figueiredo J. L (Eds.): Manual De Peixes Marinhos Do Sudeste Do Brasil. IV. Teleostei (3), Museu de Zoologia da Universidade de São Paulo, Brazil, 1980.

Menezes, N. A. and Figueiredo J. L (Eds.): Manual De Peixes Marinhos Do Sudeste Do Brasil. V. Teleostei (4) Museu de Zoologia da Universidade de São Paulo, Brazil, 1985. 
Möller, O. O., Castaing, P., Salomon, J. C. and Lazure, P.: The influence of local and non-local forcing effects on the subtidal circulation of Patos Lagoon, Estuaries., 24, 297-311, https://doi.org/10.2307/1352953, 2001.

Moraes, L. E., Paes, E., Garcia, A. M., Moller Jr. O. and Vieira, J. P.: Delayed response of fish abundance to environmental changes: a novel multivariate time-lag approach, Mar. Ecol. Prog. Ser., 456, 159-168, https://doi.org/10.3354/meps09731, 2012.

Moser, H. G. The Early Stages Of Fishes In The California Current Region, CalCOFI Atlas, EUA, 1996.

Muelbert, J. H.: Interannual variability of ichthyoplankton diversity in the Patos Lagoon estuary Southern Brazil, GBIF, https://doi.org/10.15468/noeqwa, 2020.

Muelbert, J. H.; Nidzieko, N. J.; Acosta, A. T. R.; Beaulieu, S. E.; Bernardino, A. F.; Boikova, E.; Bornman, T. G.; Cataletto, B.; Deneudt, K.; Eliason, E.; Kraberg, A.; Nakaoka, M.; Pugnetti, A.; Ragueneau, O.; Scharfe, M.; Soltwedel, T.; Sosik, H. M.; Stanisci, A.; Stefanova, K.; Stéphan, P.; Stier, A.; Wikner, J. and Zingone, A.: ILTER - The International Long-Term Ecological Research Network as a Platform for Global Coastal and Ocean Observation, Front. Mar. Sci., 6, 01-14, https://doi.org/10.3389/fmars.2019.00527, 2019.

Muxagata, E. and Teixeira-Amaral, P.: Continuous monitoring of the micro and mesozooplankton of the Patos Lagoon estuary and adjacent coastal area, GBIF, https://doi.org/10.15468/1xkowr, 2020.

Muxagata, E., Amaral, W. J. and Barbosa, C. N.: Acartia tonsa production in the Patos Lagoon estuary, Brazil, ICES J. Mar. Sci., 69, 475-482, https://doi.org/10.1093/icesjms/fsr166, 2012.

Newton, A.; Brito, A. C.; Icely, J. D.; Derolez, V.; Clara, I.; Angus, S.; Schernewski, G.; Inácio, M.; Lillebø, A. I.; Sousa, A. I.; Béjaoui, B.; Solidoro, C.; Tosic, M.; Cañedo-Argüelles, M.; Yamamuro, M.; Reizopoulou, S.; Tseng, H-C.; Canu, D.; Roselli, L.; Maanan, M.; Cristina, S.; Ruiz-Fernández, A.C.; de Lima, R. F.; Kjerfve, B.; Rubio-Cisneros, N.; Pérez-Ruzafa, A.; Marcos, C.; Pastres, R.; Pranovi, F.; Snoussi, M.; Turpie, J.; Tuchkovenko, Y.; Dyack, B.; Brookes, J.; Povilanskas, B. and Khokhlov, V.: Assessing, quantifying and valuing the ecosystem services of coastal lagoons, J. Nat. Conserv., 44, 50-65 https://doi.org/10.1016/j.jnc.2018.02.009,2018.

Odebrecht, C. and Abreu, P. C.: Phytoplankton and water quality parameters in the Patos Lagoon estuary and adjacent marine coast, GBIF, https://doi.org/10.15468/xmlvxm, 2020.

Odebrech, C. and Castello, J.P.: The Convergence Ecosystem in the Southwest Atlantic, in: Subtropical Convergence Environments: The coast and sea in the Southwestern Atlantic, edited by: Seeliger, U. and Kjerfve, B., Ecological Studies (Analysis and Synthesis), vol 144, Springer, Berlin, 145-165, https://doi.org/10.1007/978-3-662-04482-7_12, 2001.

Odebrecht, C.; Abreu, P. C.; Bemvenuti, C. E.; Copertino, M.; Muelbert, J. H.; Vieira, J. P.; and Seeliger, U.: The Patos Lagoon Estuary: biotic responses to natural and anthropogenic impacts in the last decades (1979-2008), in: Coastal lagoons: critical habitats of environmental change, edited by: Kennish, M. J. and Paerl, H. W., 437-459, 2010.

Odebrecht, C.; Abreu, P.A.; Bemvenuti, C. E.; Colling, L. A.; Copertino, M.; Costa, C. S. B.; Garcia, A. M.; Marangoni, J. C.; Moller, O. O.; Muelbert, J. H.; Vieira, J. and Seeliger, U.: O efeito de 

lições e perspectivas, edited by: Tabarelli, M., Rocha, C.F.D., Romanowski, H.P., Rocha, O. and Lacerda, L.D., Editora Universitaria UFPE, Brazil, 223-248, 2013.

Odebrecht, C., Abreu, P. C. and Carstensen, J.: Retention time generates short-term phytoplankton blooms in a shallow microtidal subtropical estuary, Estu. Coast. Shelf Sci., 162, 35-44, https://doi.org/10.1016/j.ecss.2015.03.004, 2015.

Odebrecht, C., Secchi, E. R., Abreu, P. C., Muelbert, J. H. and Uiblein, F.: Biota of the Patos Lagoon estuary and adjacent marine coast: long-term changes induced by natural and human-related factors, Mar. Biol. Res., 13, 3-8, https://doi.org/10.1080/17451000.2016.1258714, 2017.

Olivar, M. P., Moser, H. G. and Beckley, L. E.: Lanternfish larvae from the Agulhas current (SW Indian Ocean), Sci. Mar., 63, 101-120, http://researchrepository.murdoch.edu.au/id/eprint/7458, 1999.

Paerl, H. W., Yin, K. and O'Brien, T.D.: SCOR Working Group 137: Global Patterns of Phytoplankton Dynamics in Coastal Ecosystems: An introduction to the special issue of Estuarine, Coastal and Shelf Science, Estuar. Coast. Shelf Sci., 162, 1-3, https://doi.org/10.1016/j.ecss.2015.07.011, 2015.

Pilotto, F.; Kühn, I.; Adrian, R.; Alber, R.; Alignier, A.; Andrews, C.; Bäck, J.; Barbaro, L.; Beaumont, D.; Beenaerts, N.; Benham, S.; Boukal, D. S.; Bretagnolle, V.; Camatti, E.; Canullo, R.; Cardoso, P. G.; Ens, B. J.; Everaert, G.; Evtimova, V.; Feuchtmayr, H.; García-González,R.; García, D. G.; Grandin, U.; Gutowski, J. M.; Hadar, L.; Halada, L.; Halassy, M.; Hummel, H.; Huttunen, K-L.; Jaroszewicz， B.; Jensen, T. C.; Kalivoda, H.; Schmidt, I. K.; Kröncke, I.; Leinonen, R.; Martinho, F.; Meesenburg, H.; Meyer, J.; Minerbi, S.; Monteith, D.; Nikolov, B. P.; Oro, D.; Ozolinš, D.; Padedda, B. M.; Pallett, D.; Pansera, M.; Pardal, M. A.; Petriccione, B.; Pipan, T.; Pöyry, J.; Schäfer, S. M.; Schaub, M.; Schneider, S. C.; Skuja, A.; Soetaert,K.; Sprige, G.; Stanchev, R.; Stockan, J. A.; Stoll, S.; Sundqvist, L.; Thimonier, A.; Van Hoey, G.; Van Ryckegem, G.; Visser, M. E.; Vorhauser, S. and Haase, P.: Meta-analysis of multidecadal biodiversity trends in Europe, Nat. Commun., 11, 1-11, https://doi.org/10.1038/s41467-02017171-y, 2020.

Possamai, B., Vieira, J. P., Grimm, A. M. and Garcia, A. M.: Temporal variability (1997-2015) of trophic fish guilds and its relationships with El Niño events in a subtropical estuary, Estuar. Coast. Shelf Sci., 202， 145-154， https://doi.org/10.1016/j.ecss.2017.12.019, 2018.

Richards, W. J. (Ed.): Early stages of Atlantic fishes. An Identification Guide for the Western Central North Atlantic, CRC Press, Boca Raton, Florida, EUA, 2005.

Rios, E. (Ed.): Compendium of Brazilian Sea Shells, Evan Graf, Brazil, 2009.

Robertson, A. W. and Mechoso, C. R.: Interannual and Decadal Cycles in River Flows of Southeastern South America, J. Clim., 11, 2570-2581, https://doi.org/10.1175/1520-044, 1997.

Rose, M. (Ed.): Faune de France 26 - Copepodes pelagiques, Federation Francaise des Societes de Sciences Naturelles, Paris, France, 1933. 

marine communities in North America: apparent patterns, processes, and biases, Annu. Ver. Ecol. Evol. Syst., 31, 481-531, https://doi.org/10.1146/annurev.ecolsys.31.1.481, 2000.

Salvador, N. L. A. and Muelbert, J. H.: Environmental Variability and Body Condition of Argentine Menhaden Larvae, Brevoortia pectinata (Jenyns, 1842), in Estuarine and Coastal Waters, Estuaries Coasts., 42, 1654-1661, http://dx.doi.org/10.1007/s12237-019-00604-3, 2019.

Secchi, E. R.; Botta, S.; Wiegand, M. M.; Lopez, L. A.; Fruet, P. F.; Genoves, R. C. and Di Tullio, J. C.: Long-term and gender-related variation in the feeding ecology of common bottlenose dolphins inhabiting a subtropical estuary and the adjacent marine coast in the western South Atlantic, Mar. Biol. Res., 13, 121-134, https://doi.org/10.1080/17451000.2016.1213398, 2017.

Secchi, E. R., Fruet, P. and Genoves, R. C.: Ecology of Lahille's bottlenose dolphin Tursiops truncatus gephyreus in the Patos Lagoon estuary and adjacent marine coast, GBIF, https://doi.org/10.15468/4nh9ng, 2020.

Seeliger, U.: The Patos Lagoon Estuary, Brazil, in: Coastal marine ecosystems of Latin América, edited by: Seeliger, U. and Kjerfve, B., Springer, Berlin, Heidelberg, 167-183, 2001.

Seeliger, U. and Odebrecht, C. (Eds.): O Estuário da Lagoa dos Patos: um século de transformações, Editora da Furg, Brazil, 2010.

Steedman, H. F. V.: Aldehydes - 1, General and applied data on formaldehyde fixation and preservation of marine zooplankton, in: Monographs on oceanographic methodology No 4 Zooplankton fixation and preservation, edited by: Steedman, H. F., UNESCO Press. Paris, 103$154,1976$.

Strickland, J. D. and Parsons, T. R.: A practical handbook of seawater analysis, Bull. Fish. Res. Board. Can., 167, 1-309, https://doi.org/10.1002/iroh.19700550118, 1972.

Tanhua, T.; Pouliquen, S.; Hausman, J.; Obrien, K.; Bricher, P.; Bruin, T.; Buck, J. J. H.; Burger, E. F.; Carval, T.; Casey, K. S.; Diggs, S.; Giorgetti, A.; Glaves, H.; Harscoat, V.; Kinkade, D.; Muelbert, J.H.; Novellino, A.; Pfeil, B.; Pulsifer, P. L.; Putte, A. V.; Robinson, E.; Schaap, D.; Smirnov, A.; Smith, N.; Snowden, D.; , Spears, T.; Stall, S.; Tacoma, M.; Thijsse, P.; Tronstad, S.; Vandenberghe, T.; Wengren, M.; Wyborn, L. and Zhao, Z.: Ocean FAIR Data Services, Front. Mar. Sci., 6, 1-17, http://dx.doi.org/10.3389/fmars.2019.00440, 2019.

Teixeira-Amaral, P., Amaral, W. J. A., de Ortiz, D. O., Agostini, V. O. and Muxagata, E.: The mesozooplankton of the Patos Lagoon Estuary, Brazil: trends in community structure and $\begin{array}{llll}\text { secondary } & \text { production, Mar. } & \text { Biol. } & \text { Res., 13, }\end{array}$ https://doi.org/10.1080/17451000.2016.1248850, 2017.

Tomas, C. R. (Ed.): Marine Phytoplankton, Academic Press, USA, 1993.

Tomas, C. R. (Ed.): Marine Diatoms and Dinoflagellates, Academic Press, USA, 1996.

Turra, A. and Denadai, M. R.: Linking biodiversity and global environmental changes in Brazilian coastal habitats, Braz. J. Oceanogr., 64, 3-4, https://doi.org/10.1590/S1679-87592016064sp2ed, 2016.

UNESCO.: Chemical methods for use in marine environmental monitoring. Manual and Guides 12, Intergovernamental Oceanographic Commissiony, France, 1983. 
Vieillard, A. M., Newell, S. E. and Thrush, S. F.: Recovering from bias: A call for further study of underrepresented tropical and low-nutrient estuaries, J. Geophys. Res., 125, https://doi.org/10.1029/2020JG005766, 2020.

Vieira, J. P., Garcia A. M. and Grimm, A. M.: Evidences of El Niño effects on the mullet fishery of the Patos Lagoon Estuary, Braz. Arch. Biol. Technol., 51, 433-440, 2008.

Vieira, J. P., Garcia, A. M. and Moraes, L.: A assembleia de peixes, in: O Estuário da Lagoa dos Patos: Um Século de Transformações, edited by Seeliger, U. and Odebrecht, C., FURG, Rio Grande, Brazil, 79-88, 2010.

Vieira, J. P., Garcia, A. M. and Lemos, V. M.: Species composition and abundance patterns of fish assemblages at shallow waters of Patos Lagoon estuary, GBIF, https://doi.org/10.15468/kci8zb, 2020.

Vihervaara, P.; D’Amato, D.; Forsius, M.; Angelstam, P.; Baessler, C.; Balvanera, P.; Boldgiv, B.; Bourgeron, P.; Dick, J.; Kanka, R.; Klotz, S.; Maass, M.; Melecis, V.; Petrík. P.; Shibata, H.; Tang, J.; Thompson, J. and Zacharias, S.: Using long-term ecosystem service and biodiversity data to study the impacts and adaptation options in response to climate change: insights from the global ILTER sites network, Curr. Opin. Environ. Sustain., 5, 53-66, https://doi.org/10.1016/j.cosust.2012.11.002, 2013.

Von Ihering, H.: Rio Grande do Sul, Reuss, Weltpost-verlag P. Genschel, Germany, 1885.

Weiss, G. (Ed.): Ictioplâncton Del Estuário De Lagoa Dos Patos, Brasil, Faculatad de Ciências Naturales y Museo, Universidad Nacional de La Plata, Argentina, 1981.

Welschmeyer, N. A.: Fluorometric analysis of chlorophyll $a$ in the presence of chlorophyll $b$ and pheopigments, Limnol. Oceanogr. Lett., 39, 1985-1992, https://doi.org/10.4319/lo.1994.39.8.1985, 1994.

Wilkinson, M. D., Dumontier, M., Aalbersberg, I. J., Appleton, G., Axton, M., Baak, A., Blomberg, N., Boiten, J.-W., da Silva Santos, L.B., Bourne, P.E.; Bouwman, J.; Brookes, A. J.; Clark, T.; Crosas, M.; Dillo, I.; Dumon, O.; Edmunds, S.; Evelo, C. T.; Finkers, R.; Gonzalez-Beltran, A.; Gray, A. J. G.; Groth, P.; Goble, C.; Grethe, J. S.;Heringa, J.; Hoen, P.; Hooft, R.; Kuhn, T.; Kok, R.; Kok, J.; Lusher, S. J.; Martone, M. E.; Mons, A.; Packer, A. L.; Persson, B.; RoccaSerra, P.; Roos, M.; van Schaik, R.; Sansone, S-A.; Schultes, E.; Sengstag, T.; Slater, T.; Strawn, G.; Swertz, M.A.; Thompson, M.; van der Lei, J.; van Mulligen, E.; Velterop, J.; Waagmeester, A.; Wittenburg, P.; Wolstencroft, K.; Zhao, J. and Mons, B.: The FAIR Guiding Principles for scientific data management and stewardship, Sci. Data., 3, 160018, https://doi.org/10.1038/sdata.2016.18, 2016.

WoRMS: Editorial Board, World Register of Marine Species http://www.marinespecies.org at VLIZ, 2021. 